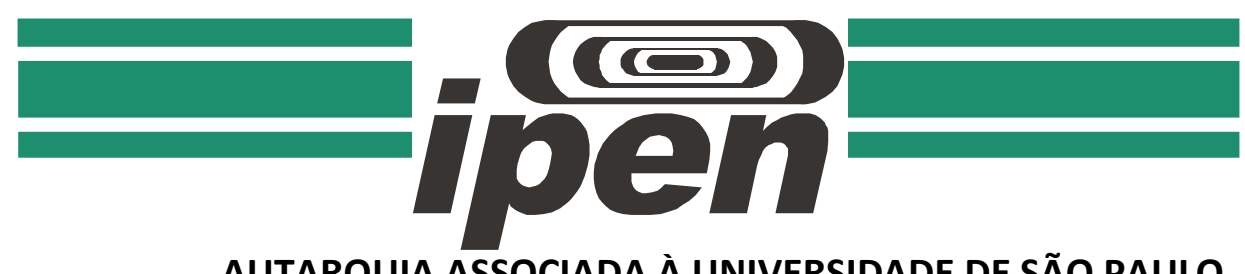

AUTARQUIA ASSOCIADA À UNIVERSIDADE DE SÃO PAULO

\title{
Estudo da Sinterização de Vidros Aluminossilicatos por Calorimetria Exploratória Diferencial
}

Juliana Pereira de Souza

Dissertação apresentada como parte dos requisitos para obtenção do Grau de Mestre em Ciências na Área de Tecnologia Nuclear - Materiais

Orientadora:

Profa. Dra. Eliana Navarro dos Santos Muccilo 


\title{
INSTITUTO DE PESQUISAS ENERGÉTICAS E NUCLEARES
}

Autarquia associada à Universidade de São Paulo

\section{Estudo da Sinterização de Vidros Aluminossilicatos por Calorimetria Exploratória Diferencial}

Juliana Pareira de Souza

\begin{abstract}
Dissertação apresentada como parte dos requisitos para obtenção do Grau de Mestre em Ciências na Área de Tecnologia Nuclear - Materiais

Orientadora:

Profa. Dra. Eliana Navarro dos Santos Muccillo
\end{abstract}

Versão Corrigida

Versão Original disponível no IPEN

São Paulo

2015 
Dedico esse trabalho à minha família e também ao meu orientador Dr. José Roberto Martinelli "in memoriam". 


\section{Agradecimentos}

Ao Dr. Jose Roberto Martinelli pelas valiosas contribuições e ensinamentos.

À Dra. Eliana Navarro Muccillo pelas sugestões e essenciais contribuições no texto da dissertação.

Aos Drs. Douglas Gouvêa, Thomaz Augusto Guisard Restivo e Frank Ferrer Sene pelas sugestões e discussões.

Ao Dr. Reginaldo Muccillo pelas sugestões e pelas análises de espectrometria de massa, termogravimetria e análise térmica diferencial.

Aos alunos do grupo LAVICOM que contribuíram na realização do trabalho, em especial ao Eraldo e à Ana Paula.

Ao MSc.Felipe Bonito Jaldin Ferrufino pelas análises de picnometria.

Ao Dr. Nelson Batista de Lima e à Caroline Gugliotti pelas análises de difração de raios $\mathrm{X}$.

À empresa Netzsch pela assistência e serviços prestados.

Ao Sr. Manoel Alves Galdino pelos serviços prestados, essenciais na montagem dos experimentos.

À CAPES pela bolsa concedida.

Ao IPEN pelo espaço e oportunidade de realização do trabalho. 


\title{
ESTUDO DA SINTERIZAÇÃO DE VIDROS ALUMINOSSILICATO POR CALORIMETRIA EXPLORATÓRIA DIFERENCIAL
}

\author{
Juliana Pereira de Souza
}

RESUMO

Neste trabalho foi investigada uma mudança na linha base observada em curvas de calorimetria exploratória diferencial em um trabalho onde microesferas de vidros aluminossilicatos contendo Ho foram estudados para a aplicação em radioterapia interna seletiva para o tratamento de carcinoma hepatocelular. Os vidros com composição nominal $53,7 \mathrm{SiO}_{2} \cdot 10,5 \mathrm{Al}_{2} \mathrm{O}_{3}$. 35,8 $\mathrm{MgO}$ em \%mol foram produzidos pelo método de fusão tradicional. As fritas obtidas foram moídas e peneiradas na faixa de 45 a $63 \mu \mathrm{m}$. $O$ material foi utilizado para produzir microesferas pelo método de esferolização por queda gravitacional. $O$ pó de vidro e as microesferas foram caracterizados por espectrometria de fluorescência de raios X, difração de laser, difração de raios X, calorimetria exploratória diferencial, análise térmica diferencial, termogravimetria, espectrometria de massa e microscopia eletrônica de varredura. Após as análises térmicas foram formadas pastilhas nos cadinhos que foram analisadas por microscopia eletrônica de varredura, difração de raios $X$ e picnometria a gás He. A mudança na linha base foi associada ao processo de sinterização por fluxo viscoso e ocorre devido a diminuição do fluxo de calor detectado devido à retração da amostra. Outros processos como cristalização concomitante com a sinterização também foram estudados.

Palavras-chave: vidros aluminossilicatos, sinterização, análises térmicas 


\title{
EVALUATION OF ALUMINOSSILICATE GLASS SINTERING DURING DIFFERENTIAL SCANNING CALORIMETRY
}

\author{
Juliana Pereira de Souza
}

\begin{abstract}
In this work a difference in the baseline in differential scanning calorimetry analyses, observed in a work where aluminosilicate glasses microspheres containing Ho were studied for application in selective internal radiotherapy as hepatocellular carcinoma treatment, was studied. The glasses with nominal composition $53,7 \mathrm{SiO}_{2} \cdot 10,5 \mathrm{Al}_{2} \mathrm{O}_{3} \cdot 35,8 \mathrm{MgO}$ in \%mol were produced from traditional melting. The frits obtained were milled and sieved in the range of $45 \mathrm{a}$ $63 \mu \mathrm{m}$. The material was used to produce glass microspheres by the gravitational fall method. The glass powder and the microspheres were characterized by $X$ ray fluorescence spectrometry, laser diffraction, $X$ ray diffraction, differential scanning calorimetry, differential thermal analysis, thermogravimetry, mass spectrometry, and scanning electron microscopy. After the thermal analyses, pellets were formed in the crucibles and were analyzed by scanning electron microscopy, $\mathrm{X}$ ray diffraction, and He picnometry. The difference in the baseline was associated to the viscous flow sintering process and happens because of the decrease in the detected heat flow due to the sample shrinkage.

Other events as concurrent crystallization with the sintering process were also studied.
\end{abstract}

Keywords: aluminosilicate glasses, sintering, thermal analyses 


\section{SUMÁRIO}

Página

1. INTRODUÇÃO

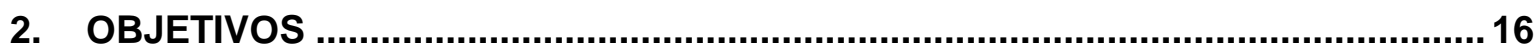

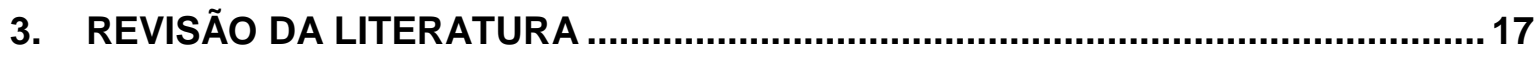

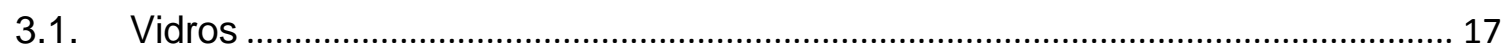

3.2. Formação de um vidro e transição vítrea ................................................................ 20

3.3. Produção de vidros, caracterização dos precursores e aplicações comerciais .. 21

3.4. Vidros Aluminossilicatos.................................................................................... 24

3.4.1. Composição e estrutura de vidros aluminossilicatos........................................ 24

3.4.2. Aplicação de vidros aluminossilicatos na radioterapia interna seletiva ........ 24

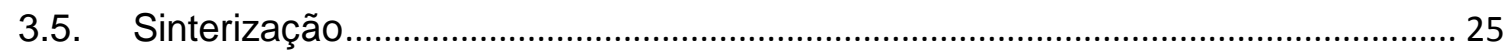

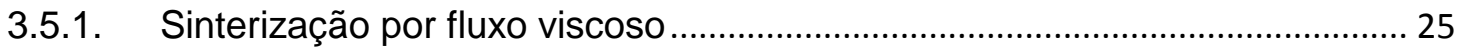

3.5.2. Técnicas de estudo de Sinterização.............................................................. 27

3.6. Descrição das técnicas de análise utilizadas............................................................2

3.6.1. Calorimetria exploratória Diferencial ........................................................... 27

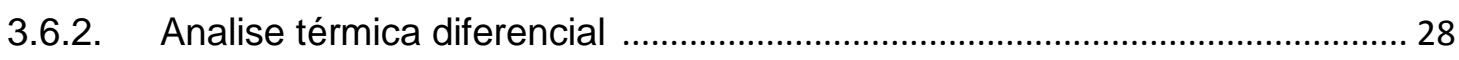

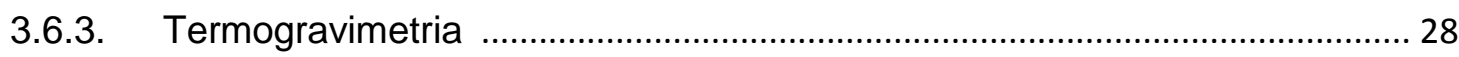

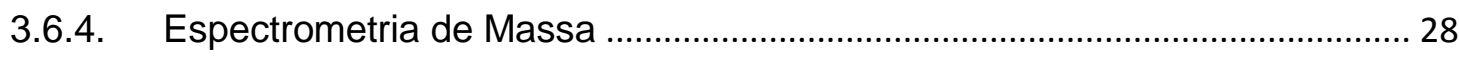

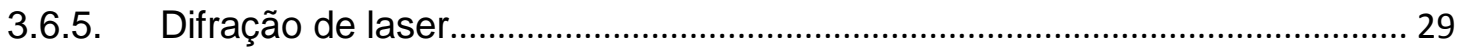

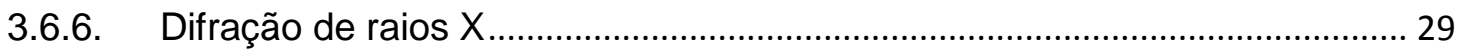

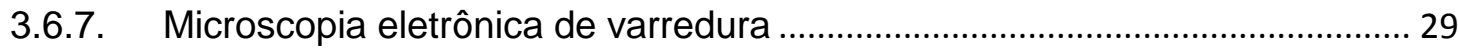

3.6.8. Espectometria de Fluorescência de raios $\mathrm{X}$...................................................... 30

3.6.9. Picnometria a gás Hélio..................................................................................... 30

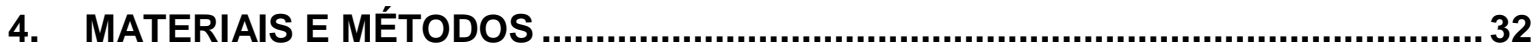

4.1. Produção do vidro ......................................................................................... 32

4.2. Moagem e Peneiramento ............................................................................. 32

4.3. Esferolização por queda gravitacional ................................................................. 32

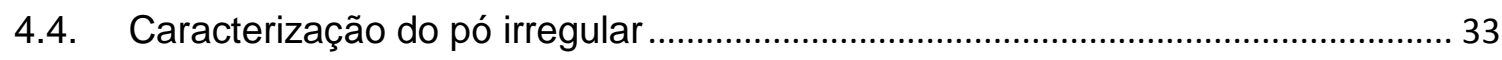

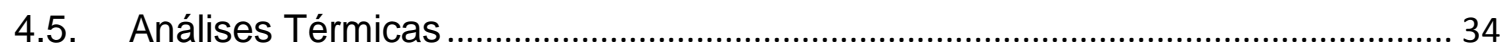

4.6. Produção de pastilhas e caracterização …………………………………………..... 35 
5.1. Espectrometria de fluorescência de raios $X$ por dispersão de energia

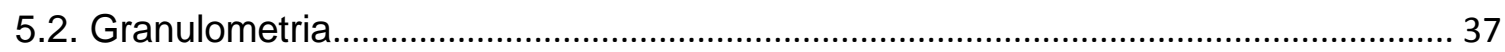

5.3. Determinação da amorfização por difração de raios $X$............................................. 41

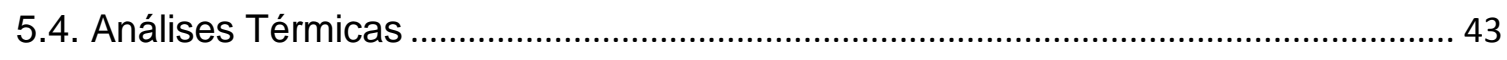

5.4.1 Calorimetria exploratória diferencial: Microesferas .............................................. 43

5.4.2. Calorimetria exploratória diferencial: pó de vidro, monolito................................. 45

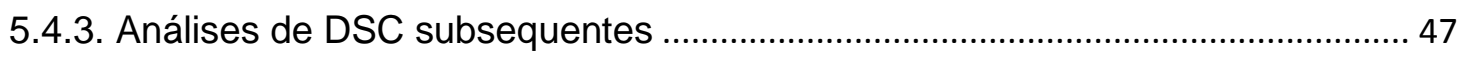

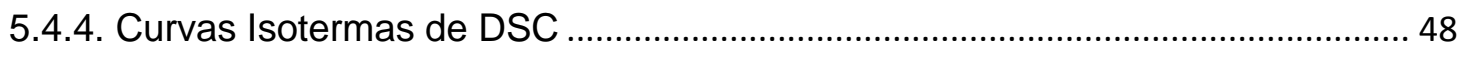

5.4.5. Resultados de DSC com cadinho de platina ....................................................... 49

5.4.6. Resultados de DSC em diferentes vidros............................................................ 51

5.4.7. Resultados de DSC em diferentes taxas de aquecimento .................................. 53

5.4.8. Resultados de DSC em diferentes granulometrias.............................................. 54

5.4.9. Resultados de DSC em diferentes atmosferas ................................................... 55

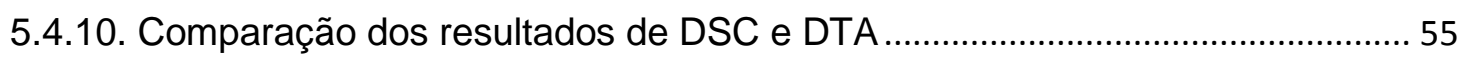

5.4.11. Termogravimetria e espectrometria de massa................................................... 57

5.5. Caracterização das pastilhas após tratamento térmico.............................................. 59

5.6. Cristalização concomitante com a sinterização ......................................................... 62

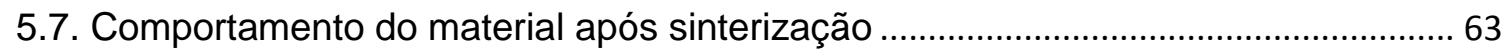

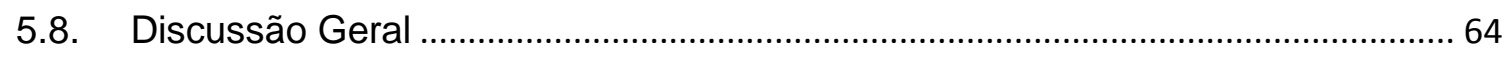

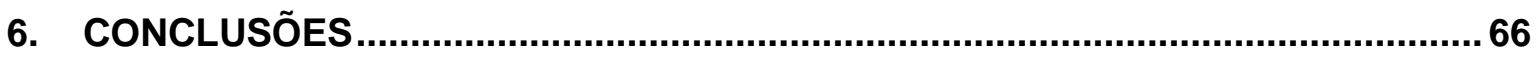

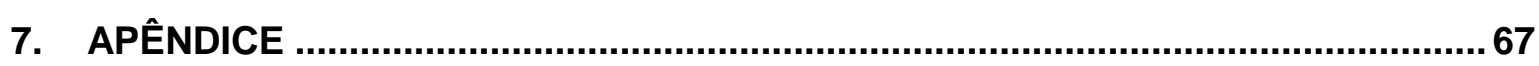

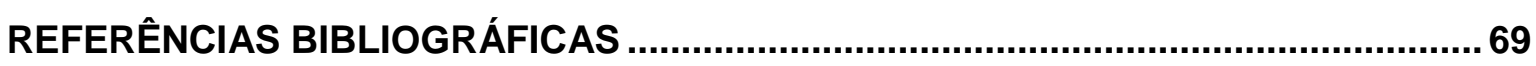




\section{LISTA DE TABELAS}

TABELA 1 : Composição nominal e composição medida por EDX do pó de vidro.

TABELA 2: Elementos identificados nas regiões clara e escura medidas por EDS durante a microscopia eletrônica de varredura.

TABELA 3: Valores médios dos diâmetros medidos utilizando o software image $J$ em função da temperatura e o desvio padrão.

TABELA 4: Valores de densidade determinada por picnometria a gás He. 61

TABELA 5: Valores médios dos diâmetros medidos utilizando o software image $J$ em função da temperatura e o desvio padrão. .63 


\section{LISTA DE FIGURAS}

FIGURA 1: Representação idealizada por Zachariassen de (a) um cristal e de (b) um vidro. Ambos com composição $\mathrm{A}_{2} \mathrm{O}_{3}$ [22]

FIGURA 2:Variação do volume específico em relação a temperatura de um vidro e de um cristal [25].

FIGURA 3:Desenho esquemático da formação de pescoços entre duas partículas esféricas, onde: $\rho$ é o raio de curvatura do pescoço formado entre as partículas, $x$ é o raio de contato entre as partículas e r é o raio das particulas[31]. .26

FIGURA 4: Aparato utilizado na obtenção de microesferas vítreas. .33

FIGURA 5: Distribuição granulométrica do pó irregular peneirado na faixa de 45 a $63 \mu \mathrm{m}$. Diâmetro médio: $68 \mu \mathrm{m}$. 38

FIGURA 6: Micrografia do pó de vidro estudado após o processo de peneiramento na faixa de 45-63 $\mu \mathrm{m}$. Aumento 200x.

FIGURA 7: Distribuição granulométrica das microesferas produzidas a partir do pó peneirado na faixa de 45 a $63 \mu \mathrm{m}$. Diâmetro médio: $93 \mu \mathrm{m}$. 40

FIGURA 8: Micrografia das microesferas produzidas a partir do pó de vidro peneirado na faixa de $45-63 \mu \mathrm{m}$. Aumento 150x.

FIGURA 9: Difratograma de raios $X$ do pó de vidro.

FIGURA 10: Difratograma de raios $X$ das microesferas vítreas.

FIGURA 11: Curva DSC de um vidro aluminossilicato contendo hólmio (taxa de aquecimento: $10^{\circ} \mathrm{C} / \mathrm{min}$. Atmosfera: ar sintético) [18].

FIGURA 12: Curva DSC das microesferas vítreas (taxa de aquecimento: $10^{\circ} \mathrm{C} / \mathrm{min}$. Atmosfera: ar sintético). 
FIGURA 13: Imagem de MEV de microesferas de vidro aluminossilicato contendo hólmio após aquecimento a 950oC [18].

FIGURA 14: Curvas de calorimetria exploratória diferencial de amostras do vidro em pó solto e em um monólito. A temperatura de transição (tg) vítrea foi determinada na faixa de $808-820^{\circ} \mathrm{C}$. As análises foram realizadas em atmosfera de ar sintético dinâmico, com velocidades de aquecimento de $10^{\circ} \mathrm{C} / \mathrm{min}$ em cadinhos de alumina. .45

FIGURA 15: Imagem parcial do sistema DSC, focalizando o cadinho com a amostra monolítica e o cadinho de referência. Ambos cadinhos são de alumina. 46

FIGURA 16: Imagem de uma pastilha formada dentro de um cadinho após uma análise de DSC. É possível observar a retração da pastilha dentro do cadinho...47

FIGURA 17: Curvas de DSC de amostras do vidro na forma de pó em duas etapas: aquecimento até $1000^{\circ} \mathrm{C}$, com posterior resfriamento até a temperatura ambiente, e reaquecimento até $1300^{\circ} \mathrm{C}$. As análises foram realizadas em atmosfera de ar sintético dinâmico, velocidade de aquecimento de $10^{\circ} \mathrm{C} / \mathrm{min}$ em cadinho de alumina. Foi inserida uma linha pontilhada acompanhando a linha base para melhor vizualição do início do pico de cristalização em $950^{\circ} \mathrm{C}$ .48

FIGURA 18: Curvas isotérmicas de DSC. Atmosfera de ar sintético em cadinhos de alumina 49

FIGURA 19: Curva de DSC do material em ar sintético, a $10^{\circ} \mathrm{C} / \mathrm{min}$ em um cadinho de platina. .50

FIGURA 20: Curva de DSC do material analisado em atmosfera de argônio, a $10^{\circ} \mathrm{C} / \mathrm{min}$ em um cadinho de platina. A análise foi realizada pela empresa Netzsch em um forno de platina.

FIGURA 21: Curva de DSC de um vidro fosfato, analisado em atmosfera de ar sintético, a $10^{\circ} \mathrm{C} / \mathrm{min}$ em um cadinho de alumina. 
FIGURA 22: Imagem de uma pastilha formada dentro de um cadinho após uma análise de DSC de um vidro fosfato estudado no laboratório. É possível observar a retração da pastilha dentro do cadinho.

FIGURA 23: Curvas de DSC do material em ar sintético, a $10^{\circ} \mathrm{C} / \mathrm{min}$ e a $20^{\circ} \mathrm{C} / \mathrm{min}$ em cadinhos de alumina. .53

FIGURA 24: Curvas de DSC do material em ar sintético, a $10^{\circ} \mathrm{C} / \mathrm{min}$, em cadinhos de alumina, em duas faixas granulométricas: abaixo de $25 \mu \mathrm{m}$ e de 45 a $63 \mu \mathrm{m} . .54$

FIGURA 25: Curvas de análises de DSC realizadas em atmosferas distintas, a $10^{\circ} \mathrm{C} / \mathrm{min}$ em cadinhos de alumina. .55

FIGURA 26: Curvas de DSC e DTA do material em atmosfera de ar sintético, a $10^{\circ} \mathrm{C} /$ min em cadinhos de alumina. .56

FIGURA 27: Desenho esquemático das montagens e cadinhos de a) DTA e b) DSC [44]. .56

FIGURA 28: Curvas de análise termogravimetrica e DTA do material. A análise foi realizada em atmosfera de nitrogênio, a $10^{\circ} \mathrm{C} / \mathrm{min}$ em cadinho de alumina.

FIGURA 29: Curva de análise de espectrometria de massa para os íons de $\mathrm{O}_{2}$. Os números 16 e 32 são os valores das massas.atômicas monitoradas. .58

FIGURA 30: Curva de análise de espectrometria de massa para os íons de $\mathrm{CO}_{2}$. Os números 12, 16, 22, 28, 29, 44, 45 e 46 são os valores das massas.atômicas monitoradas. .58

FIGURA 31: Curva de análise de espectrometria de massa para os íons de $\mathrm{H}_{2} \mathrm{O}$. Os números 1, 16, 17 e 18 são os valores das massas.atômicas monitoradas....59

FIGURA 32: Micrografias das pastilhas obtidas a a) $940^{\circ} \mathrm{C}$, b) $960^{\circ} \mathrm{C}$, c) $980^{\circ} \mathrm{C} \mathrm{e}$ d) $1000^{\circ} \mathrm{C}$. As setas vermelhas indicam a formação de pescoços entre as partículas. 60

FIGURA 33: Difratogramas de raios $\mathrm{X}$ das pastilhas tratadas térmicamente a $960^{\circ} \mathrm{C}, 980^{\circ} \mathrm{C}$ e $1000^{\circ} \mathrm{C}$. 
FIGURA 34: Difratograma de raios $\mathrm{X}$ das pastilhas tratadas de $1000^{\circ} \mathrm{C}$ a $1300^{\circ} \mathrm{C}$.

FIGURA 35: Desenho esquemático da montagem no forno tubular utilizada para produzir as pastilhas estudadas

FIGURA 36: Comparação dos valores de temperatura em função do tempo de análise medidos no temopar controlador, no termopar auxiliar inserido no lugar da amostra e reta representando o programa de aquecimento de $10^{\circ} \mathrm{C} / \mathrm{min}$ .68 


\section{INTRODUÇÃO}

Dentre as possibilidades para o tratamento do Carcinoma Hepatocelular $(\mathrm{CHC})$ não eletivos para procedimentos cirúrgicos ou transplante destaca-se a radioterapia interna seletiva [1]. Esta terapia utiliza microesferas de vidro contendo radionuclídeos emissores de partículas $\beta^{-}$, as quais são introduzidas no fígado por meio de um cateter acoplado à artéria hepática. Quando as microesferas atingem o fígado, migram preferencialmente para regiões hipervasculares, que são características da presença de tecido canceroso. As microesferas são então apresadas nos pequenos vasos sanguíneos que alimentam o tumor. A emissão de partículas $\beta$ e o bloqueio das vias que alimentam o tumor, impedem o crescimento do mesmo causando a aniquilação das células cancerosas [2,3]. Portanto, tanto a forma das partículas, preferencialmente esféricas para evitar arestas cortantes e impedir o dano nos tecidos sadios e hemorragias desnecessárias durante o translado na corrente sanguínea, como o tamanho das partículas, para que possam fluir pelos vasos sanguíneos, é muito importante para o sucesso desta terapia [4].

O processo de preparação de microesferas de vidro consiste na esferolização de partículas vítreas com formas irregulares a partir da redução da viscosidade com o aumento da temperatura. Isto é geralmente obtido a partir da passagem das partículas através de uma zona quente de um forno ou de uma chama. A radioterapia interna seletiva já está sendo utilizada em vários países. Microesferas de vidro aluminossilicatos dopados com ${ }^{90} \mathrm{Y}$ são disponíveis comercialmente (MDS Nordion Canadá (Theraspheres $\left.{ }^{\circledR}\right)$ )) assim como microesferas poliméricas (Sirtex, Medical Ltda, Austrália ( SIRSphere $\left.{ }^{\circledR}\right)$ ). Essa terapia possui um relativo sucesso como relatado na literatura [6,7], porém, o uso de radionuclídeos alternativos esta sendo investigado em substituição ao ${ }^{90} \mathrm{Y}$. Exemplos desta substituição são: ${ }^{32} \mathrm{P}[8,9]$, ${ }^{188} \mathrm{Re}[10],{ }^{131} \mathrm{I}[11]$, ${ }^{177} \mathrm{Lu}[12]$ e em especial o ${ }^{166} \mathrm{Ho}\left({ }^{166} \mathrm{Ho}\right.$ : $\mathrm{E}_{\beta}=1,77-1,85 \mathrm{MeV}$; 
$\mathrm{E} \gamma=81 \mathrm{keV} ; \quad \mathrm{t}_{1 / 2}=26,8 \mathrm{~h} ; \sigma=64$ barns) produzido por meio da reação nuclear ${ }^{165} \mathrm{Ho}(\mathrm{n}, \gamma){ }^{166} \mathrm{Ho}$, cuja emissão $\beta$ tem um alcance máximo de $8,5 \mathrm{~mm}$ no tecido humano, alta energia e meia vida relativamente curta $[13,14]$. $O{ }^{165} \mathrm{Ho}$ tem alta seção de choque para absorção de nêutrons, possibilitando a ativação neutrônica em reatores de baixa potência e baixo fluxo de nêutrons térmicos, como no caso do reator nuclear do IPEN, IEA-R1, além de serem emissores combinados $\beta$ e $\gamma$, sendo por isso potencialmente usados para produção de imagens por tomografia computadorizada por emissão de fótons (SPECT), além de serem altamente paramagnéticos possibilitando a produção de imagens por ressonância magnética [15]. Estas modalidades de imageamento são úteis para a avaliação da biodistribuição e permitem a dosimetria por meio de análises quantitativas de cintilografia e imagens de ressonância magnética [16]. Além disso, o hólmio tem uma abundância de 100\% na natureza permitindo produzir uma atividade de $344 \mathrm{mCi}(\sim 12 \mathrm{GBq}$ ) (reator IEA-R1, 60 horas, $4,0 \times 10^{13} \mathrm{n} \cdot \mathrm{s}^{-1} \cdot \mathrm{cm}^{-2}$ ), o suficiente para produção de doses terapêuticas [17].

As técnicas de radioterapia interna seletiva desenvolvidas e consolidadas no Brasil ainda não abrangem a utilização de microesferas de vidro para o tratamento de tumores e não há nenhum trabalho de produção e caracterização deste tipo de material para aplicações radioterápicas.

Em trabalho previamente desenvolvido no IPEN [18], mostrou-se a possibilidade de desenvolvimento de vidros aluminossilicatos contendo hólmio para uso nesta terapia. No entanto, as propriedades térmicas deste material ainda não são completamente conhecidas. Em resultados preliminares foram obtidas curvas de Calorimetria Exploratória Diferencial (DSC) cujas características não correspondem às normalmente observadas em sistemas amorfos, onde reações endotérmicas e exotérmicas vinculadas aos fenômenos de relaxamento atômico e cristalização são esperados.

Observou-se uma reação endotérmica em $825^{\circ} \mathrm{C}$, que pode ser vinculada à transição vítrea, no entanto as demais reações observadas não haviam sido estudadas para a determinação dos possíveis mecanismos envolvidos na estabilização térmica deste material. Foi observada uma mudança na linha base abaixo de $1000^{\circ} \mathrm{C}$ que não está presente em curvas 
típicas de DSC para vidros. Em uma micrografia do material aquecido a $950^{\circ} \mathrm{C}$ foi observada a formação de pescoços na interface das microesferas.

Com base nesses resultados, questionou-se se os efeitos de sinterização seriam responsáveis pela mudança de linha base a $1000^{\circ} \mathrm{C}$, ou se esta reação estaria vinculada à presença de outras fases amorfas ou processos de cristalização. Não foram encontrados trabalhos na literatura científica de ampla divulgação que correlacionassem medidas de análises térmicas diferenciais com os efeitos observados durante a sinterização de materiais por fluxo viscoso. 


\section{OBJETIVOS}

O presente trabalho tem como objetivo o estudo da mudança na linha base observada nas curvas de DSC das microesferas de vidros aluminossilicatos para tratamento do $\mathrm{CHC}$, sua correlação com o processo de sinterização e a comparação com outras técnicas utilizadas no estudo do processo de sinterização. Para isto, será investigada a estabilidade térmica de vidros aluminossilicatos na forma de partículas e microesferas, que apresentam potencial para aplicação em radioterapia interna seletiva, utilizando análises térmicas, difratometria de raios $\mathrm{X}$ e microscopia eletrônica de varredura. 


\section{REVISÃO DA LITERATURA}

\subsection{Vidros}

Vidros naturais podem ser encontrados na natureza quando alguns tipos de rocha são fundidos em altas temperaturas como ocorre em erupções vulcânicas. $\mathrm{Na}$ idade da pedra os humanos já usavam rochas obsidianas e tektites em ferramentas de corte. Os vidros naturais já foram considerados materiais preciosos e utilizados em adornos, sendo encontrados em tumbas e máscaras mortuárias de antigos faraós [19].

O início da fabricação dos vidros é incerto, há relatos que em cerca de 7000 a.C. os fenícios improvisavam fogões utilizando blocos de salitre sobre a areia e observaram a formação de uma substância fluida e brilhante que se solidificava rapidamente $[19,20]$.

A técnica de sopragem foi desenvolvida por artesãos sírios da região da Babilônia e Bidon em 200 a.C.. Os primeiros vidros incolores foram produzidos em Alexandria por volta de 100 d.C. devido à incorporação de óxido de manganês nas composições e melhorias nos fornos [19].

Os vidros sempre foram utilizados em materiais utilitários, mas o período do império romano é considerado a era de luxo do vidro, onde o refinamento da arte de trabalhar com vidros permitia a criação de joias e imitações perfeitas de pedras preciosas. No século XV era possível a produção de pequenos pedaços de vidros polidos utilizados em vitrais de igrejas, catedrais, palácios, átrios e residências [19,21].

Em 1612, Neri publicou L'Arte Vetraria, onde eram reportadas técnicas utilizadas para trabalhar com vidros. Um maior entendimento da ciência do vidro só poderia surgir com um melhor entendimento da química e da física para que fosse possível diferenciar as propriedades de matérias primas como sódio, potássio, magnésio e cálcio, e o entendimento do que era calor, até então entendido por alguns como uma forma de elemento químico [19]. 
Os primeiros estudos científicos em vidros foram realizados por Michael Faraday, em 1830, o qual definiu vidros como sendo materiais "mais aparentados a uma solução de diferentes substâncias do que um composto em si". As primeiras definições de vidro se baseavam no conceito de viscosidade de sólidos, pois até então esses materiais eram preparados por fusão e resfriamento. Definiu-se vidro como "um material formado pelo resfriamento do estado líquido normal (ou fundido), o qual exibe mudanças contínuas em qualquer temperatura, tornando-se mais ou menos rígido através de um progressivo aumento da viscosidade, acompanhado da redução da temperatura do fundido". Tal definição poderia ser assim resumida: "vidro é um produto inorgânico fundido que atinge, por resfriamento, uma condição rígida sem que ocorra cristalização" [19].

Em 1921, Lebedev propôs a hipótese do cristalito, onde o vidro era considerado "um fundido comum consistindo de cristais altamente dispersos". Ele já levava em conta a inter-relação entre as propriedades e a estrutura interna dos vidros [19].

Em 1932 Zachariassen publicou o famoso artigo The Atomic Arrangement in Glass (O Arranjo Atômico em Vidros), onde afirmava que nada era conhecido sobre o arranjo atômico dos vidros óxidos $\left(\mathrm{M}_{\mathrm{x}} \mathrm{O}_{\mathrm{y}}\right)$. Ele propôs que "o arranjo atômico em vidros era caracterizado por uma rede tridimensional estendida, a qual apresentava ausência de simetria e periodicidade" e que "as forças interatômicas eram comparáveis àquelas do cristal correspondente" (figura 1). Ele também afirmou que a presença ou ausência de periodicidade e simetria em uma rede tridimensional seria o fator de diferenciação entre um cristal e um vidro [19,22]. 


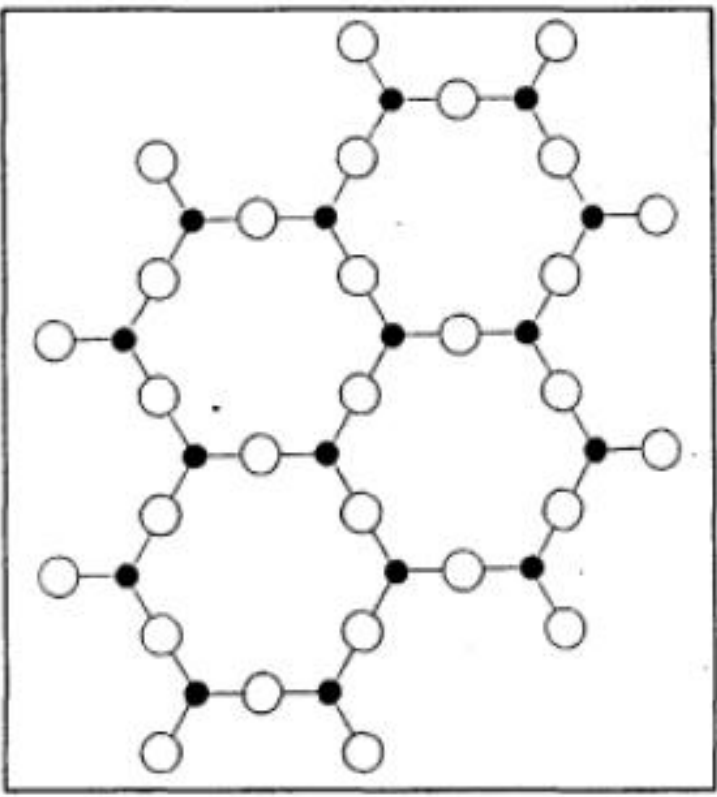

(a)

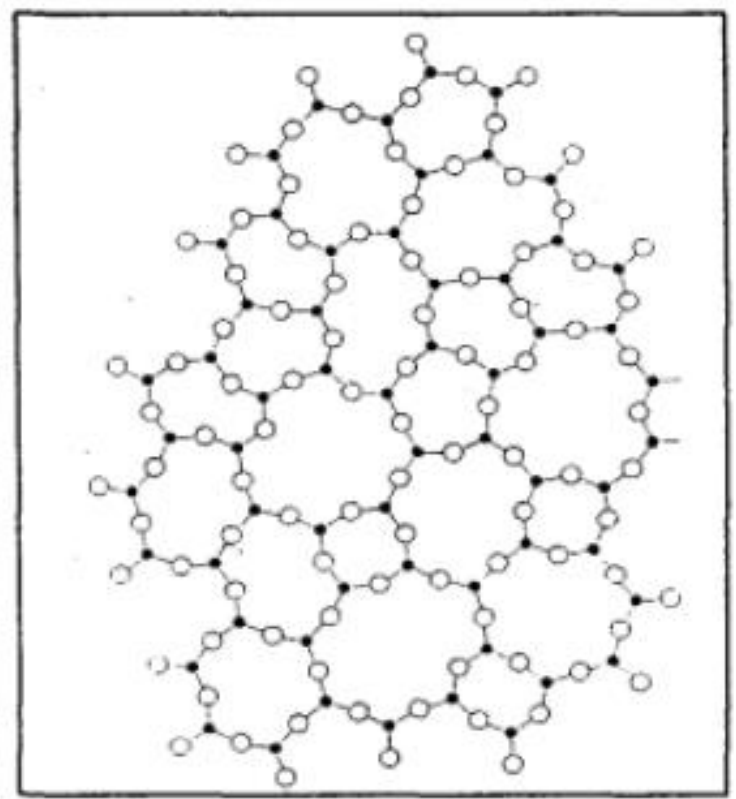

(b)

FIGURA 1: Representação idealizada por Zachariassen de (a) um cristal e de (b) um vidro. Ambos com composição $\mathrm{A}_{2} \mathrm{O}_{3}$ [22].

Utilizando os conceitos da época e a hipótese de Zachariassen seria possível chegar a seguinte definição: "vidro é um produto inorgânico fundido, baseado principalmente em sílica, o qual foi resfriado para uma condição rígida sem cristalização, formando uma rede tridimensional estendida aleatória, isto é, com ausência de simetria e periodicidade". Mas essa definição não é adequada pois existem muitos vidros que não são formados por sílica, existem vidros orgânicos e metálicos e vidros podem ser produzidos por vários processos que não a fusão como deposição química de vapor, pirólise, irradiação de nêutrons e processo sol-gel, entre outros [19,22].

A partir dessas afirmações surgiram definições distintas para vidros. Em 1995 Gupta publicou em seu artigo Non-Crystalline Solids: Glasses and Amorphous Solids (Sólidos Não-Cristalinos: Vidros e Sólidos Amorfos) que um sólido não cristalino pode ser dividido, do ponto de vista termodinâmico, em duas classes distintas: vidros e sólidos amorfos. Sólidos não-cristalinos seriam todos aqueles materiais que apresentassem uma rede tridimensional estendida e aleatória, isto é, com ausência de simetria e periodicidade translacional. 
Considerando-se o aspecto termodinâmico, um sólido não cristalino seria um vidro quando este apresentasse o fenômeno de transição vítrea. Consequentemente, sólidos amorfos seriam sólidos não cristalinos que não exibissem a transição vítrea $[19,23,24]$

\subsection{Formação de um vidro e transição vítrea}

Os vidros convencionais são tradicionalmente produzidos através do método de fusão e resfriamento, onde materiais de partida são fundidos, em geral a altas temperaturas, e o fundido é resfriado rapidamente, permitindo que a estrutura atômica se mantenha semelhante a de um líquido [19].

De acordo com a taxa de resfriamento do fundido o arranjo estrutural interno do material pode se comportar de maneiras diferentes. Na figura 2 observa-se a variação do volume em relação a temperatura de resfriamento de dois arranjos atômicos diferentes: um vidro e de um cristal. Quando se fala nos diferentes arranjos internos, é o mesmo que dizer que existem diferentes ordenações atômicas que apresentam diferentes quantidades de espaço vazio entre os átomos. Um ordenamento organizado apresenta uma menor quantidade de espaços vazios entre os átomos, mas se os átomos forem desordenados (como o arranjo atômico de um líquido) existirá uma maior quantidade de espaço entre os átomos. Acima do ponto de fusão o material se encontra no estado líquido em equilíbrio, conforme visto na figura 2, o material pode ser resfriado de $A$ até $C$ e abaixo da temperatura de solidificação $\left(T_{f}\right)$ haverá a formação de cristais com ordem atômica a longo alcance, formando uma rede cristalina. $O$ seu volume diminuirá abruptamente de $B$ a $C$ e de $C$ a $D$ esse sólido se contrairá de acordo com seu coeficiente de expansão térmica. $O$ arranjo atômico de um fundido, quando resfriado, pode assumir uma forma ordenada em um arranjo cristalino ou sem ordem a longo alcance em um arranjo vítreo. Se por outro lado o líquido for resfriado rápido o suficiente para que não haja a cristalização de $B$ a $E$ haverá um líquido super-resfriado, ou metaestável. $O$ movimento de translação dos átomos continua conforme a temperatura diminui, mas não existe um rearranjo cristalino. A viscosidade do líquido aumenta e os átomos perdem mobilidade até o ponto $\mathrm{F}$ do diagrama onde o material pode ser denominado vidro $[19,25]$. 


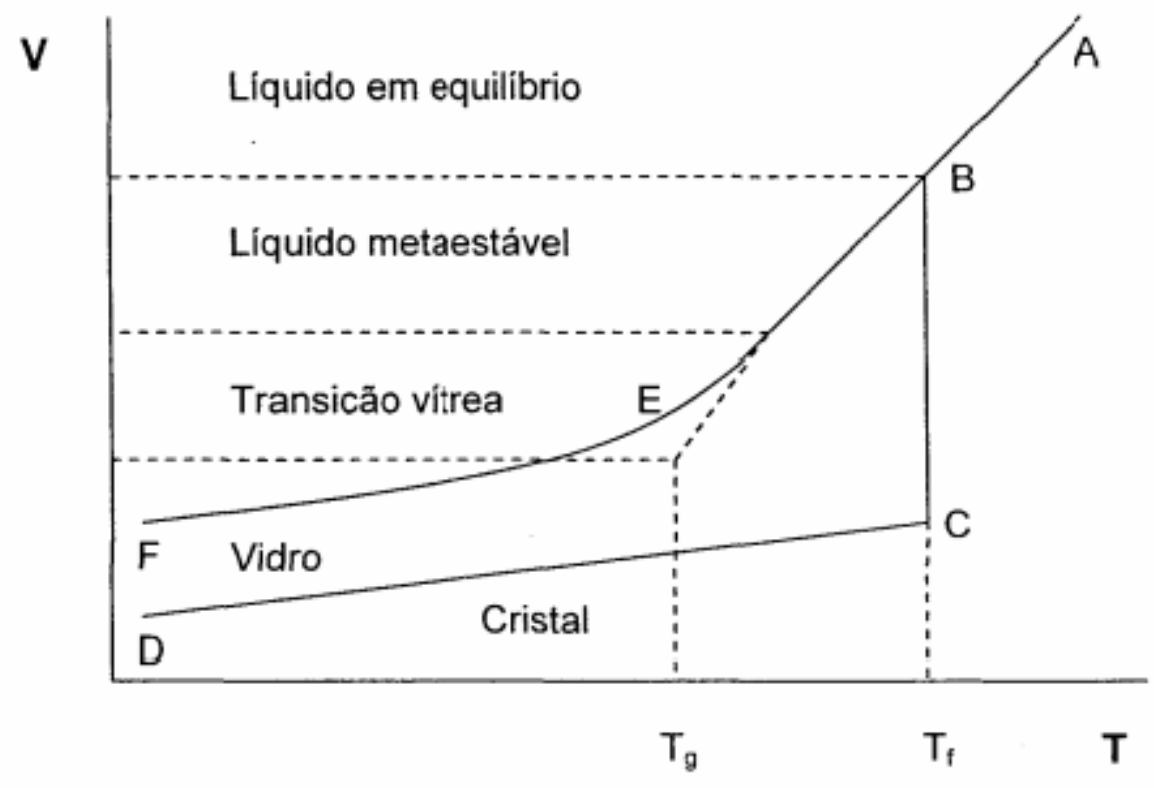

FIGURA 2:Variação do volume específico em relação a temperatura de um vidro e de um cristal [25].

A temperatura na intersecção entre as linhas extrapoladas, que definem o estado metaestável e o estado vítreo é definida como temperatura de transição vítrea $(\mathrm{Tg})$. Nessa faixa de temperatura ocorre a chamada relaxação estrutural, quando algumas propriedades como viscosidade, capacidade calorífica e expansão térmica começam a apresentar um comportamento diferente do verificado até então. A temperatura de transição vítrea, $\mathrm{Tg}$, é uma temperatura característica para os vidros, definindo a passagem do estado vítreo para o estado viscoelástico, através da chamada relaxação estrutural [19].

\subsection{Produção de vidros, caracterização dos precursores e aplicações comerciais}

Vidros podem ser produzidos de diversas maneiras, mas a maioria continua sendo produzido pela fusão dos precursores a altas temperaturas. As matérias primas podem ser divididas em cinco categorias de acordo com sua 
função: formador, intermediário, agente modificador, agente de cor e agente de refino $[19,26]$.

Os formadores constituem a maior parte da rede tridimensional e os principais são $\mathrm{SiO}_{2}, \mathrm{~B}_{2} \mathrm{O}_{3}$ e $\mathrm{P}_{2} \mathrm{O}_{5}$. A grande maioria dos vidros comerciais é baseada em sílica, mas vidros puros de sílica só podem ser obtidos em temperaturas superiores a $2000^{\circ} \mathrm{C}$. Para reduzir a temperatura de fusão dos vidros são utilizados os fundentes (um tipo de modificador), sendo os mais comuns os óxidos de metais alcalinos ( $\mathrm{Li}, \mathrm{Na}$ e $\mathrm{K}$ ) e o $\mathrm{PbO}$. A adição de fundentes pode prejudicar algumas propriedades dos vidros como durabilidade química e por isso são utilizados agentes modificadores, que permitem um controle maior dessas propriedades. Os agentes modificadores incluem óxidos de metais de transição e de terras-raras e, principalmente a alumina. Os agentes de refino promovem a remoção de bolhas no fundido e são utilizados em quantidades mínimas. São utilizados óxidos de antimônio e arsênio, $\mathrm{KNO}_{3}$, $\mathrm{NaNO}_{3}, \mathrm{NaCl}, \mathrm{CaF}_{2}, \mathrm{NaF}, \mathrm{Na}_{3} \mathrm{AlF}$ e alguns sulfatos, Os agentes de cor são utilizados para dar cor aos vidros, e os compostos usualmente utilizados são de metais de transição $3 d$ ou terras-raras $4 f$ [19].

A produção de vidros comerciais requer a obtenção de formatos específicos. A moldagem do vidro pode ser feita por: sopro, prensagem, fundição e estiramento/flutuação. Após a moldagem os vidros são geralmente submetidos a processos de recozimento para remover tensões internas que podem ser criadas na moldagem. A temperatura de recozimento é inferior à temperatura de transição vítrea. Para o aumento da resistência mecânica o vidro pode passar pelo processo de têmpera, onde é reaquecido até tornar-se quase maleável e subitamente resfriado [19].

As seis mais importantes composições básicas de vidro levando-se em conta suas aplicações comerciais são [19]:

- "Soda-silicato": que apresentam composição variável e tem uma razão de $\mathrm{SiO}_{2}$ e $\mathrm{Na}_{2} \mathrm{O}$ pré-determinada. São utilizados em agentes complexantes em detergentes sintéticos e em banhos de limpeza para metais;

- "Soda-lime" silicato: São constituídos de $\mathrm{SiO}_{2}, \mathrm{Na}_{2} \mathrm{O}, \mathrm{CaO}$ e $\mathrm{Al}_{2} \mathrm{O}_{3}$ e são utilizados em invólucros de lâmpadas incandescentes, garrafas, janelas, 
isolantes elétricos, blocos de vidro para construção, embalagens de alimentos e fármacos etc;

- Borossilicato: Constituídos de $\mathrm{SiO}_{2}, \mathrm{Na}_{2} \mathrm{O}, \mathrm{B}_{2} \mathrm{O}_{3}$ e $\mathrm{Al}_{2} \mathrm{O}_{3}$ e são utilizados em instrumentos de laboratório (béquers, pipetas, buretas, kitassatos, dessecadores, tubos de ensaio). As denominações Pirex® e Kimax® são marcas registradas de vidros borossilicatos, respectivamente da Corning e da Owens-Illinois (USA);

- Aluminossilicato: Seus componentes são $\mathrm{SiO}_{2}, \mathrm{CaO}, \mathrm{Al}_{2} \mathrm{O}_{3}$, e podem conter $\mathrm{Na}_{2} \mathrm{O}, \mathrm{K} 2 \mathrm{O}, \mathrm{MgO}$ e $\mathrm{B}_{2} \mathrm{O}_{3}$ e são usados em fibras de vidro (reforço de plásticos e concreto), isolamento com fibras de vidro resistentes à hidrólise (decomposição pela água), lã de vidro (isolante térmico), fabricação de filtros, roupas e cortinas a prova de fogo, tampos de fogões, invólucros de lâmpadas de mercúrio de alta pressão, vidros do tipo opalina (contém 5,3\% de fluoretos e apresentam aspecto leitoso) usados como louças e objetos de decoração e para visualizar filmes revelados de raios $X$;

- Silicato de chumbo: Apresenta alto teor de $\mathrm{PbO}$, além de $\mathrm{SiO}_{2}$, e podem conter $\mathrm{Na}_{2} \mathrm{O}, \mathrm{K}_{2} \mathrm{O}, \mathrm{B}_{2} \mathrm{O}_{3}$ e $\mathrm{Al}_{2} \mathrm{O}_{3}$. É comumente chamado "cristal", e é utilizado em jogos de utensílios de mesa e em peças artísticas, devido à facilidade para gravação e polimento; também empregado na fabricação de instrumentos ópticos (lentes, prismas), tubos de TV, anteparos para blindagem de radiação y e como vidro para solda;

- Alta Sílica: vidros que apresentam um teor de $\mathrm{SiO}_{2}$ superior a $96 \%$ e que, devido a sua elevada resistência química e térmica (fundem em torno de $200{ }^{\circ} \mathrm{C}$ ), são utilizados em equipamentos especiais de laboratório, cadinhos, recipientes para reações a altas temperaturas, invólucros para lâmpadas de altas temperaturas e pré-formas para fibras ópticas.

Outra importante aplicação comercial para vidros são as vitro-cerâmicas. São materiais que são constituídos por uma fase vítrea e outra cristalina (com nucleação e crescimento de cristais). Algumas vitro-cerâmicas apresentam coeficiente de dilatação térmica próximo do zero e resistem a choques térmicos extremos [19]. 


\subsection{Vidros Aluminossilicatos}

\subsubsection{Composição e estrutura de vidros aluminossilicatos}

Vidros aluminossilicatos são compostos de $\mathrm{SiO}_{2}, \mathrm{CaO}, \mathrm{Al}_{2} \mathrm{O}_{3}$, e podem conter $\mathrm{Na}_{2} \mathrm{O}, \mathrm{K}_{2} \mathrm{O}, \mathrm{MgO}$ e $\mathrm{B}_{2} \mathrm{O}_{3}$ e são usados em diversas aplicações comerciais como citado anteriormente. Os vidros aluminossilicato também podem ser encontrados na natureza como os do tipo obsidiana encontrados no monte Vesúvio na Itália [19].

O vidro aluminossilicato estudado no presente trabalho apresenta como precursores $\mathrm{SiO}_{2}, \mathrm{Al}_{2} \mathrm{O}_{3}$ e $\mathrm{MgO}$ [18]. O óxido de magnésio age como modificador, aumentando o módulo de elasticidade e a durabilidade química do vidro $[18,19,26]$.

Apesar do alumínio não ser um formador de vidros, em vidros aluminossilicatos, assume uma coordenação tetraédrica similar ao silício. Ele é um agente intermediário. Como o alumínio é trivalente e o silício tetravalente, o tetraedro formado pelas ligações entre alumínio e oxigênio diminui o número de oxigênios, aumentando a coesão da estrutura. Por este motivo esses vidros podem ser aquecidos a altas temperaturas sem a ocorrência de deformações como ocorre com vidros borossilicatos e soda-cal [27].

\subsubsection{Aplicação de vidros aluminossilicatos na radioterapia interna seletiva}

Os vidros aluminossilicatos podem ser utilizados como hospedeiros de radionuclídeos, pois seus constituintes apresentam baixa seção de choque para absorção de nêutrons [28]. Alguns vidros aluminossilicatos são inertes quando em contato com tecidos humanos e são considerados biocompátiveis. Devido a esses fatores vidros aluminossilicatos de magnésio são boas matrizes para a produção de microesferas vítreas contendo radionuclídeos para o tratamento do carcinoma hepatocelular por meio de radioterapia interna seletiva. Nesse processo as microesferas são introduzidas no fígado por meio da artéria hepática e do fígado migram para regiões hipervascularizadas, 
características da presença de tecidos cancerosos. As microesferas ficam presas nos pequenos vaso que alimentam o tumor e a emissão de partículas $\beta$ e o bloqueio da alimentação aniquilam o tecido canceroso [2, 3, 4, 18].

\subsection{Sinterização}

Sinterização é o nome dado à um processo termodinâmico que promove a consolidação de materiais particulados em altas temperaturas. A sinterização não costuma ocorrer até o material atingir de metade a dois terços da temperatura de fusão, que é suficiente para permitir a difusão atômica no caso de sinterização em estado sólido ou uma difusão atômica significante e um fluxo viscoso de fases líquidas presentes. Esse processo permite a consolidação e, geralmente, a densificação de peças a partir do material particulado, sem que seja necessária a fusão dos precursores $[29,30]$.

\subsubsection{Sinterização por fluxo viscoso}

O caso mais simples de sinterização por fase única ocorre quando um agregado de partículas vítreas é aquecido. Em um estado inicial, a retração da amostra, a densificação e eliminação de poros ocorrem em uma taxa determinada pelo tamanho inicial de partícula, energia superficial e viscosidade do vidro. Conforme as partículas começam a coalescer, o pescoço formado na interface entre elas apresenta um raio de curvatura que permanece pequeno comparado à curvatura das partículas, resultando uma pressão negativa que causa um fluxo viscoso em direção a região de contato das mesmas (figura 3) [31]. Em um trabalho clássico, J. Frenkel alegou que o aumento do raio de contato, $\mathrm{x}$, é proporcional a $t^{1 / 2}$. [32]. 


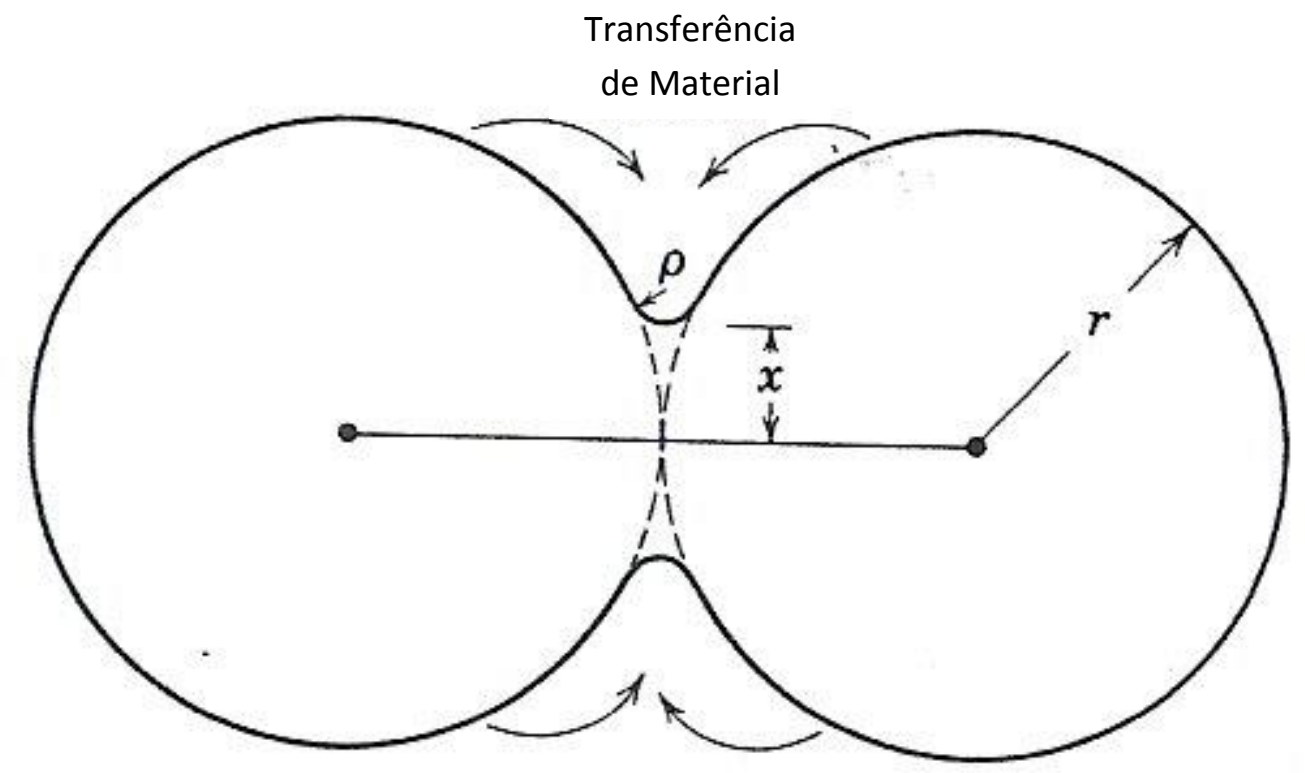

FIGURA 3: Desenho esquemático da formação de pescoços entre duas partículas esféricas, onde: $\rho$ é o raio de curvatura do pescoço formado entre as partículas, $x$ é o raio de contato entre as partículas e r é o raio das partículas [31].

O modelo de Frenkel oferece uma descrição do início do processo de sinterização, onde a taxa de crescimento de pescoço inicial é dada pela equação [31,33]:

$$
\frac{x}{r}=\left(\frac{3 \gamma}{2 \eta r} t\right)^{1 / 2}
$$

O resultado macroscópico dessa coalescência é a retração do compacto do pó. A retração linear é determinada pela aproximação dos centros das partículas. A retração, y, é dada pela equação [31]:

$$
y \approx \rho \approx \frac{x^{2}}{4 r}
$$


E a retração linear é dada pela equação:

$$
\frac{y}{r}=\frac{\Delta L}{L_{0}}=\frac{\Delta V}{3 V_{0}}=\frac{3 \gamma}{8 \eta(T) r} t
$$

Após um tempo de sinterização, quando a pressão negativa exercida nos poros entre as partículas é igual a $2 \gamma / a$, sendo a o raio do poro, o modelo de J. K. Mackenzie e R. Shuttleworth pode ser aplicado. A equação mostra a variação da densidade $\rho^{\prime}$ em relação ao tempo [31, 33, 34]:

$$
\frac{d \rho^{\prime}}{d t}=\frac{3 \gamma}{2 a_{0} \eta(T)}\left(1-\rho^{\prime}\right)
$$

\subsubsection{Técnicas de estudo de Sinterização}

As técnicas mais convencionais para o estudo dos processos de sinterização estão relacionadas à determinação direta da densidade e retração do material, destacando-se a picnometria e dilatometria, respectivamente. As características microestruturais podem também prover informações sobre os processos de sinterização.

\subsection{Descrição das técnicas de análise utilizadas}

\subsubsection{Calorimetria exploratória diferencial [35]}

A calorimetria exploratória, do inglês Differential Scanning Calorimetry (DSC) mede a mudança de energia que ocorre quando uma amostra é aquecida, resfriada ou mantida em uma temperatura constante e a temperatura em que essas mudanças ocorrem. A principal propriedade medida é o fluxo de calor liberado ou absorvido pela amostra.

Os cadinhos utilizados podem ser de vários materiais, como alumina, platina, ouro, zircônia, entre outros. O contato do cadinho com o termopar é superficial. É necessário verificar se a amostra é inerte com o tipo de cadinho utilizado e se este é adequado para a faixa de temperatura analisada. Os cadinhos também devem ser limpos e as amostras devem ter um bom contato com o fundo do cadinho. A taxa de aquecimento/resfriamento durante a análise 
pode influenciar na temperatura em que um evento ocorre e na largura do pico medido. Também podem ser variados os gases utilizados durante a análise e seu fluxo, os mais comuns são nitrogênio, argônio e ar sintético.

Alguns eventos medidos são: fusão, detectado como um pico endotérmico; transição vítrea, detectada como uma mudança na linha base; cristalização, detectada como um pico exotérmico; entre outros.

\subsubsection{Analise térmica diferencial [35]}

A análise térmica diferencial, do inglês Differential Thermal Analysis (DTA), mede a diferença de temperatura entre a amostra e a referência. Outra diferença importante em relação à análise de DSC é o formato do cadinho, onde o contato com o termopar é pontual. Os materiais dos cadinhos e condições de análise são iguais aos do DSC.

\subsubsection{Termogravimetria [35]}

A análise termogravimétrica, do inglês Thermogravimetric Analysis (TGA), mede a massa da amostra em função da temperatura. Alguns processos estudados são: evaporação de constituintes voláteis, oxidação em ar ou oxigênio, reações de redução, perda de água da amostra, entre outros.

Equipamentos modernos medem sinais de DTA juntamente com o sinal de TGA. As análises simultâneas podem oferecer informações complementares.

\subsubsection{Espectrometria de massa [36]}

As análises de espectrometria de massa mede a liberação de gases em função da temperatura. Um espectrômetro de massa identifica as diferentes moléculas que constituem uma substância identificando suas massas, podendo distinguir até mesmo massas de isótopos. A medida costuma ser realizada juntamente com outras análises como TGA e DTA. 


\subsubsection{Difração de laser [37]}

A técnica de difração de laser utiliza padrões de difração de um feixe de laser que passa um partícula para medir suas dimensões geométricas. $O$ padrão de difração depende do diâmetro da partícula (D) e do comprimento de onda do laser incidente $(\lambda)$, e dependendo da razão $D / \lambda$ a difração pode ser do tipo Fraunhofer, Mie e Rayleigh. A difração Fraunhofer ocorre quando o tamanho de partícula é pelo menos 5 ou 6 vezes maior do que o comprimento de onda do laser, o espalhamento Rayleigh quando o tamanho de partícula é menor que o comprimento de onda e o Mie quando a razão $D / \lambda$ é em torno de um.

Durante a medida as partículas devem ser dispersas em um fluído no qual o material a ser analisado não seja solúvel, e pode ser usado um dispersante e ultrassom para desaglomerar as partículas se necessário.

\subsubsection{Difração de raios $X$ [38]}

A difração de raios $X$ é uma ferramenta para a investigação da microestrutura da matéria. Quando um feixe de raios $X$ com comprimento de onda conhecido difrata em um cristal, através da medida dos ângulos de difração obtidos é possível determinar a estrutura cristalina.

O arranjo atômico periódico da estrutura cristalina faz com que somente os feixes de raios $X$ que apresentam ângulos que satisfazem a lei de Bragg sejam espalhados construtivamente, criando os picos que podem ser observados em um difratograma de um material cristalino. Imperfeições na rede causam o alargamento e deslocamento desses picos. Líquidos e sólidos amorfos não apresentam uma periodicidade na rede e seus difratogramas não apresentam picos, somente halos.

\subsubsection{Microscopia eletrônica de varredura [39]}

A microscopia eletrônica de varredura é uma técnica utilizada para examinar e analisar as características microestruturais de objetos sólidos. Em um microscópio eletrônico de varredura, elétrons são emitidos termoionicamente a partir de um cátodo e acelerados através de um anôdo por 
efeito de emissão de campo. Quando o feixe interage com a amostra, os elétrons perdem energia e como resultado são emitidos elétrons secundários, elétrons retroespalhados, elétrons Auger, raios $X$ (Bremstralun $e$ característicos), radiação eletromagnética na região do infravermelho, visível e ultravioleta, e fônons.

A resolução atingida é da ordem de $100 \AA$ e a profundidade de foco é cerca de 300 vezes melhor que a do microscópio ótico. Utilizando-se elétrons de baixa energia $(50 \mathrm{eV})$ podem ser obtidas informações topográficas, e com elétrons de alta energia se obtém informações sobre número atômico ou orientação. Em amostras magnéticas pode se obter informações sobre domínio ou caracterizar falhas em dispositivos semicondutores com os sinais obtidos devido a condutividade induzida pelo feixe e luz catodoluminescente.

\subsubsection{Espectrometria de fluorescência de raios X [40]}

A espectrometria de fluorescência de raios $X$ é uma técnica utilizada na determinação dos elementos presentes em uma amostra através da fluorescência de raios $X$ característicos de uma amostra bombardeada com um feixe de raios $X$ de alta energia ou raios gama.

Os espectrômetros de raios $X$ podem ser de três tipos:

- Por dispersão de comprimento de onda - WD

- Por dispersão de energia - ED

- Por reflexão total - TR

As principais diferenças estão relacionadas com a fonte de excitação, o número de elementos que podem ser detectados, a velocidade na determinação, o nível de concentração a ser determinado e o custo do equipamento.

\subsubsection{Picnometria a gás hélio [41]}

A picnometria a gás é uma técnica que determina o volume real de um sólido, mesmo que poroso, por variação de pressão em uma câmara de volume conhecido. Normalmente o gás hélio é utilizado por ser inerte e penetrar facilmente nos poros abertos da amostra devido ao pequeno tamanho de seus 
átomos. Um picnômetro de hélio é constituído por duas câmaras de volumes conhecidos, uma onde a amostra é colocada e outra chamada de câmara de expansão, ligadas por uma válvula. Essa técnica tem como vantagem a medida de amostras com diferentes formatos e porosidades. 


\section{MATERIAIS E MÉTODOS}

\subsection{Produção do vidro}

Vidros aluminossilicatos de magnésio foram produzidos a partir de misturas de $\mathrm{Al}_{2} \mathrm{O}_{3}, \mathrm{SiO}_{2}$ e $\mathrm{MgO}\left(\mathrm{O} \mathrm{Al} \mathrm{O}_{3}\right.$ e o $\mathrm{MgO}$ apresentam grau analítico e são da marca Vetec, o $\mathrm{SiO}_{2}$ apresenta pureza de $99 \%$. Os componentes foram pesados em uma balança analítica (Mettler Toledo) na proporção de 53,7 $\mathrm{SiO}_{2} \cdot 10,5 \mathrm{Al}_{2} \mathrm{O}_{3} .35,8 \mathrm{MgO} \mathrm{em} \% \mathrm{~mol}$. A composição nominal foi escolhida a partir de trabalhos anteriores [18]. A mistura foi homogeneizada com o auxílio de um gral e de um pistilo de porcelana e fundida em um forno elétrico (Carbolite) a $1550^{\circ} \mathrm{C}$, com taxa de aquecimento de $10^{\circ} \mathrm{C} / \mathrm{min}$ e mantido a $1550^{\circ} \mathrm{C}$ por 30 minutos. A fusão foi feita em um cadinho de alumina destampado.

O líquido foi vertido em um molde de aço inoxidável na forma de bulk ou em água na forma de fritas vítreas que foram retiradas da água e mantidas em estufa por 2 horas a $90^{\circ} \mathrm{C}$.

\subsection{Moagem e Peneiramento}

As fritas de vidro foram maceradas em um embolo de aço inoxidável 304 e o material obtido foi moído em um moinho planetário com uma esfera de tungstênio (modelo pulverizette, Fritsch) por 20 minutos. $O$ pó de vidro obtido foi peneirado na faixa de 45 a $63 \mu \mathrm{m}$ por 1 hora em peneiras de aço inoxidável (Abronzinox) sobre um agitador de peneiras eletromagnético para análises granulométricas (Bertel).

\subsection{Esferolização por queda gravitacional}

Para obtenção das microesferas o material peneirado foi submetido ao processo de esferolização por queda gravitacional. A figura 4 mostra um diagrama do aparato utilizado na esferolização do pó de vidro. Nesse processo 
o pó, na faixa de 45 a $63 \mu \mathrm{m}$, foi depositado com o auxílio de uma espátula vibratória em um colimador em um tubo de alumina por dentro de um forno tubular a $1420^{\circ} \mathrm{C}$. Devido a alta temperatura, a viscosidade do vidro diminuiu e durante a queda livre as partículas adquiriram a forma de microesferas e foram coletadas na parte inferior do forno. A temperatura utilizada no processo de esferolização e faixa granulométrica do pó irregular foram escolhidos a partir de dados previamente reportados em [18].

1. Espátula vibratória

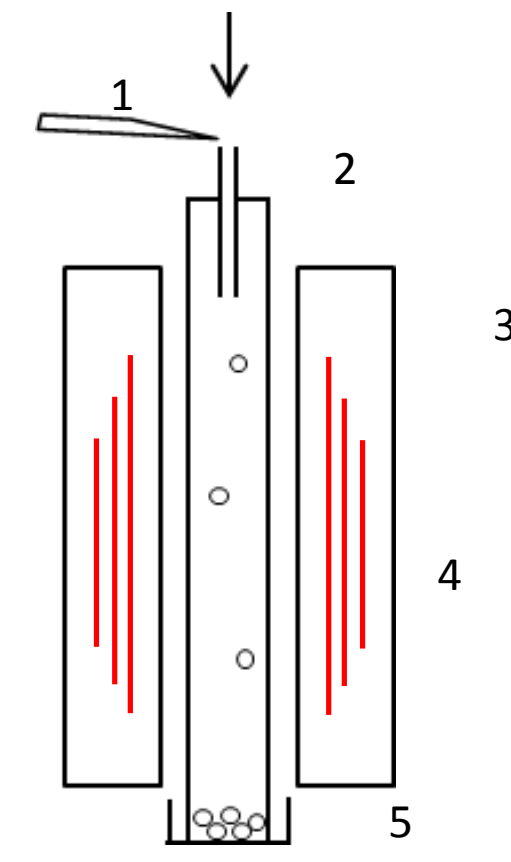

FIGURA 4: Aparato experimental utilizado na obtenção de microesferas vítreas.

\subsection{Caracterização do pó de vidro}

As amostras na forma de pó foram analisadas por espectrometria de fluorescência de raios $X$ por dispersão de energia em um equipamento da Shimadzu, modelo EDX-720, para determinar sua composição. O material foi analisado na forma de pó sobre um filme de polipropileno de $5 \mu \mathrm{m}$ de espessura, utilizando um colimador de $10 \mathrm{~mm}$. $O$ erro foi determinado a partir do ajuste do espectro obtido com os espectros dos constituintes individuais.

Para determinar o grau de cristalinidade das amostras e identificar possíveis fases foram feitas medidas de difração de raios $X$. $O$ difratômetro utilizado foi o modelo multiflex, da Rigaku. As análises foram feitas a $2 \%$ min, no 
intervalo angular de $10^{\circ}$ a $90^{\circ}$, com tensão de $40 \mathrm{kV}$ e corrente de $20 \mathrm{~mA}$. $\mathrm{O}$ ânodo utilizado foi de cobre (radiação $\mathrm{CuK}_{\alpha}$ ).

As distribuições granulométricas dos pós e das microesferas foram determinadas por difração de laser, em um equipamento Cilas, modelo 1064. O meio líquido utilizado foi água destilada. Não foi usado nenhum dispersante e a análise foi feita com o uso de ultrassom por $60 \mathrm{~s}$.

\subsection{Análises Térmicas}

Para investigar os eventos endotérmicos e exotérmicos até $1300 \stackrel{\circ}{\circ}$ foram feitas análises de calorimetria exploratória diferencial (DSC). O equipamento utilizado foi da marca Netzsch, modelo 404 Pegasus. As análises foram feitas em um forno de carbeto de silício. As análises foram feitas em atmosfera dinâmica de ar sintético, em cadinhos de alumina com taxa de aquecimento de $10^{\circ} \mathrm{C} / \mathrm{min}$ até $1300^{\circ} \mathrm{C}$. O pó na faixa de 45 a $63 \mu \mathrm{m}$ foi utilizado nesta análise.

As análises foram divididas em:

- Material na forma de microesferas: para comparação com o material citado na referência [18];

- Material na forma de pó e monólito: para observar o aparecimento dos eventos estudados;

- Subsequentes: $\mathrm{O}$ pó de vidro foi aquecido até $1000^{\circ} \mathrm{C}$, resfriado até a temperatura ambiente e reaquecido até $1300^{\circ} \mathrm{C}$, para estudar a influência da ciclagem térmica nos eventos investigados;

- Isotermas: $\mathrm{O}$ material foi aquecido até $900^{\circ} \mathrm{C}, 920^{\circ} \mathrm{C}$ e $950^{\circ} \mathrm{C}$ e analisado nessas temperaturas por alguns minutos;

- Cadinhos de platina: Para verificar a influência de diferentes cadinhos na detecção dos eventos estudados. Também foi comparado um resultado obtido em um laboratório da empresa Netzsch que foi analisado em um forno de platina, em atmosfera de argônio, em um cadinho de platina a $10^{\circ} \mathrm{C} / \mathrm{min}$; 
- Vidro fosfato: Foi utilizada a curva de um vidro fosfato analisado em trabalho anterior no grupo para critério de comparação;

- Diferentes taxas de aquecimento: Para avaliar a influência de diferentes taxas de aquecimento nos eventos estudados. As análises foram realizadas a $10^{\circ} \mathrm{C} / \mathrm{min}$ e a $20^{\circ} \mathrm{C} / \mathrm{min}$;

- Diferentes granulometrias: Para estudar a influência da granulometria estudada foi feita também a análise do material na forma de pó peneirado abaixo de $25 \mu \mathrm{m}$;

- Diferentes atmosferas: Para verificar se a atmosfera altera os eventos detectados foram feitas análises em atmosferas dinâmicas de argônio e nitrogênio, além de ar sintético.

Foi realizada uma análise térmica diferencial (DTA) para comparação com as medidas de DSC. As condições de análise foram mantidas (cadinhos de alumina, atmosfera de ar sintético, taxa de aquecimento de $\left.10^{\circ} \mathrm{C} / \mathrm{min}\right)$.

O material foi analisado por espectrometria de massa (Pfeiffer Vacuum, modelo thermostar GSD 320) acoplada a termogravimetria e análise térmica diferencial (Netzsch, modelo STA 402-E) para determinação da perda de massa e identificação dos gases liberados.

\subsection{Produção de pastilhas e caracterização}

Após análises no DSC em diferentes temperaturas e taxas, foram obtidas pastilhas que puderam ser facilmente retiradas dos cadinhos. Novas pastilhas também foram produzidas em um forno tubular previamente calibrado simulando as condições das análises térmicas. A montagem e calibração do forno tubular estão descritas no apêndice.

As pastilhas foram analisadas por picnometria a gás He (Micromeritics, modelo AccuPyc 1130), para determinar sua densidade durante o processo estudado.

Também foram feitos estudos de difração de raios $X$ das pastilhas para verificar possível cristalização e consequente identificação das fases cristalina. 
As condições de análise e equipamento foram os mesmos utilizados para as análises do material na forma de pó.

A estrutura das pastilhas foi analisada por microscopia eletrônica de varredura (MEV), (Hitachi, modelo TM3000), com o uso da fluorescência de raios $X$ por dispersão de energia (EDS), para verificar a distribuição dos elementos e identificar possíveis contaminantes. Estas análises também foram utilizadas para avaliar a variação dos raios das pastilhas durante 0 aquecimento. 


\section{RESULTADOS E DISCUSSÃO}

\subsection{Espectrometria de fluorescência de raios $X$ por dispersão de energia}

A composição nominal do vidro estudado foi tomada como base para calcular a massa dos precursores utilizados e então comparada com os valores medidos por meio de espectrometria de fluorescência de raios $X$ por dispersão de energia (EDX). A tabela 1 apresenta os resultados determinados por EDX.

TABELA 1 : Composição nominal e composição medida por EDX do pó de vidro.

\begin{tabular}{ccc}
\hline & $\begin{array}{c}\text { Composição Nominal } \\
\text { (\% massa) }\end{array}$ & $\begin{array}{c}\text { Composição Medida } \\
\text { (\% massa) }\end{array}$ \\
\hline $\mathrm{SiO}_{2}$ & 56,21 & $57,39 \pm 0,06$ \\
$\mathrm{Al}_{2} \mathrm{O}_{3}$ & 18,65 & $22,27 \pm 0,06$ \\
$\mathrm{MgO}$ & 25,14 & $19,91 \pm 0,10$ \\
Contaminantes & - & $<1$ \\
\hline
\end{tabular}

Os valores da composição final são muito próximos da nominal; a diferença observada pode ser atribuída ao aumento do teor de alumina proveniente do uso de um cadinho de alumina para a fusão dos precursores. Também foram detectados os seguintes contaminantes em teores relativamente baixos ( $<1 \%$ em massa): $\mathrm{CaO}, \mathrm{Fe}_{2} \mathrm{O}_{3}, \mathrm{CuO}, \mathrm{ZrO}_{2}$ e $\mathrm{SO}_{3}$. Os contaminantes foram identificados na composição dos cadinhos e dos precursores utilizados.

\subsection{Granulometria}

A distribuição granulométrica do pó de vidro foi determinada por difração de laser (figura 5). $\mathrm{O}$ diâmetro médio determinado é de $68 \mu \mathrm{m}$. É evidente a 
presença de partículas com diâmetros na faixa de 1 a $10 \mu \mathrm{m}$ assim como reportado previamente [18]. Apesar da seleção das partículas ter ocorrido na faixa de 45 e $63 \mu \mathrm{m}$ pelo processo de peneiramento, o diâmetro médio determinado é de $68 \mu \mathrm{m}$. Este resultado pode ser explicado considerando que as partículas não são esféricas e apresentam razão de aspecto maior do que 1 .

O aspecto morfológico do pó pode ser observado na micrografia da figura 6. Tanto na análise por difração de laser quanto na micrografia é possível observar a presença de partículas com dimensões da ordem de poucas micras. A presença dessas partículas ocorre pois estas ficam aderidas às partículas maiores no processo de peneiramento, assim como relatado previamente [18].

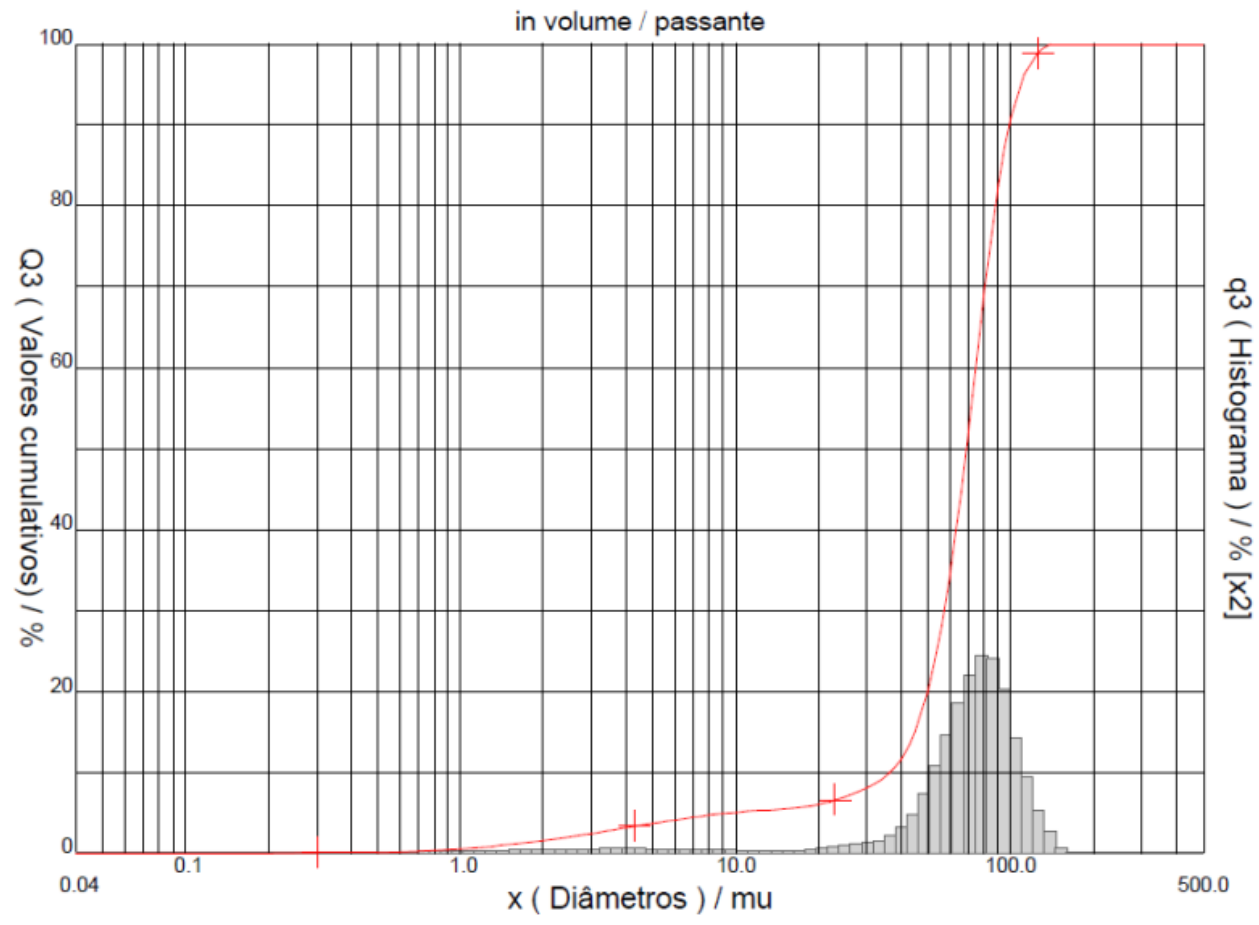

FIGURA 5: Distribuição granulométrica do pó peneirado na faixa de 45 a 63

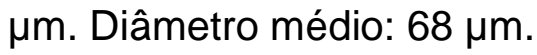




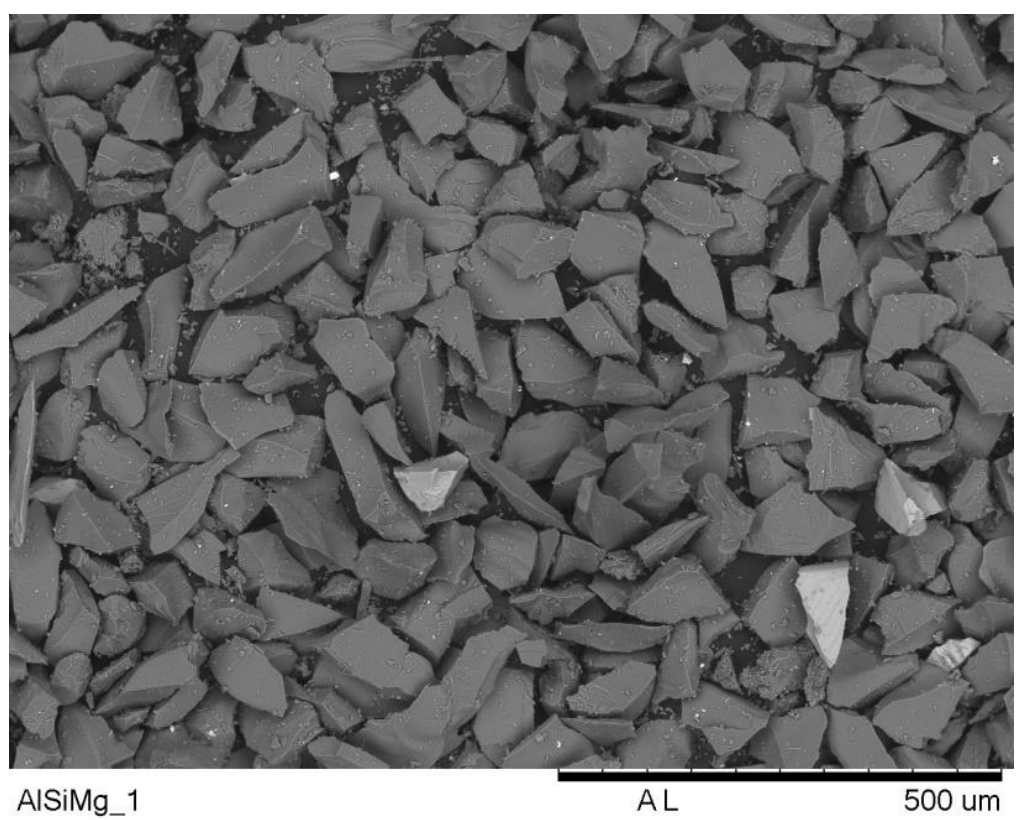

FIGURA 6: Micrografia do pó de vidro estudado após o processo de peneiramento na faixa de $45-63 \mu \mathrm{m}$. Aumento 200x.

A distribuição granulométrica das microesferas produzidas a partir do pó de vidro medida por difração a laser está apresentada na figura 7. O diâmetro médio determinado foi de $93 \mu \mathrm{m}$, maior do que o diâmetro médio do pó peneirado utilizado para a produção das microesferas. Esse resultado pode ser explicado devido a formação de aglomerados que permanecem unidos devido a fatores atuantes, como forças de van der Waals, e coalescem formando uma única microesfera durante o processo de esferolização. Esse fenômeno foi observado no trabalho anterior [18]. 


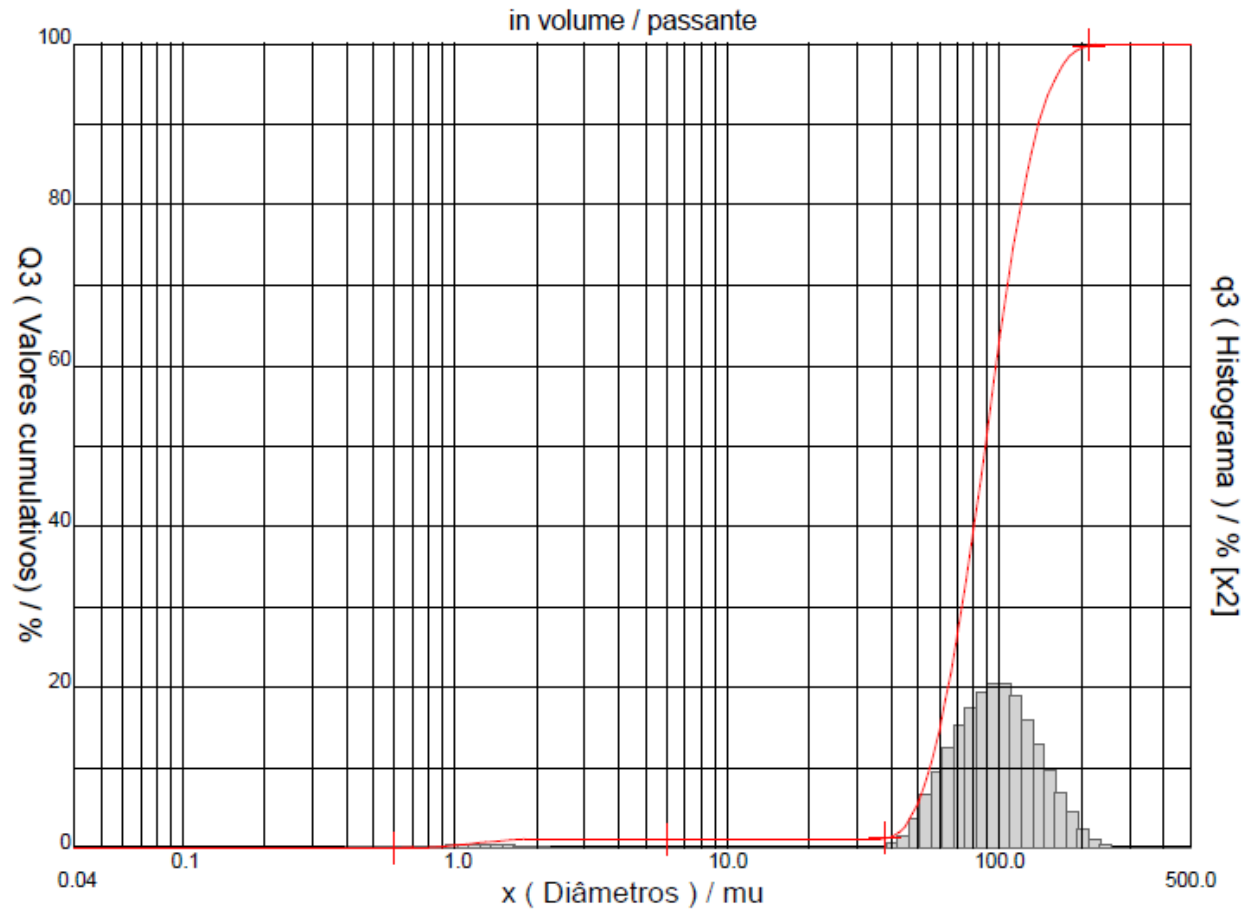

FIGURA 7: Distribuição granulométrica das microesferas produzidas a partir do pó peneirado na faixa de 45 a $63 \mu \mathrm{m}$. Diâmetro médio: $93 \mu \mathrm{m}$.

Foi feita observação no MEV das microesferas. Nas imagens obtidas observam-se algumas microesferas com coloração mais clara (figura 8) Essa diferença de coloração já podia ser observada na micrografia do pó de vidro (figura 6). Foram feitas então medidas de EDS nas regiões mais escuras e mais claras para verificar uma possível diferença na composição. A tabela 2 apresenta os valores de composição encontrados para cada região. Foi observado um aumento no teor de Ca nessas regiões devido à separação de fases e cristalização superficial. $\mathrm{O} \mathrm{Ca}$ foi identificado como um contaminante presente nos precursores utilizados. 


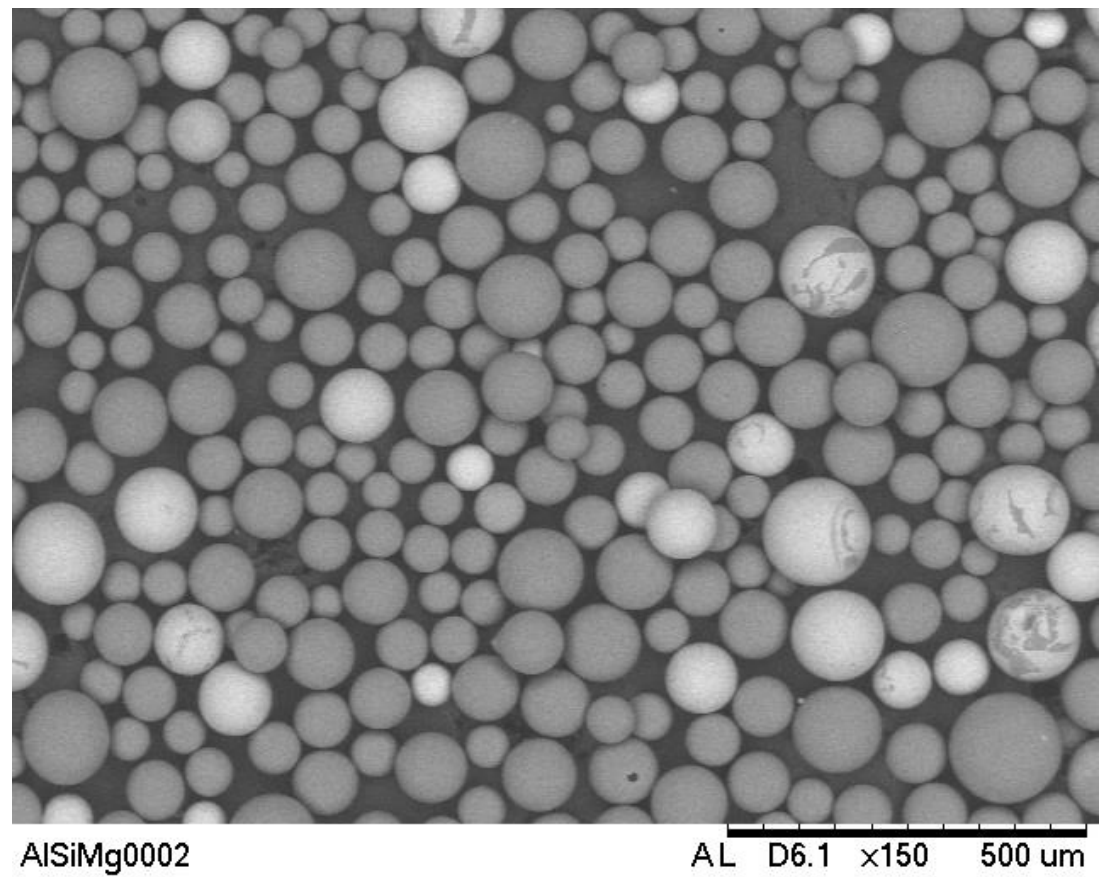

FIGURA 8: Micrografia das microesferas produzidas a partir do pó de vidro peneirado na faixa de $45-63 \mu \mathrm{m}$. Aumento 150x.

TABELA 2: Elementos identificados nas regiões clara e escura medidas por EDS durante a microscopia eletrônica de varredura.

\begin{tabular}{ccc}
\hline & $\begin{array}{c}\text { Região escura } \\
\text { (\% massa) }\end{array}$ & $\begin{array}{c}\text { Região clara } \\
\text { (\% massa) }\end{array}$ \\
\hline $\mathbf{S i}$ & 56,0 & 30,3 \\
$\mathbf{A l}$ & 22,2 & 18,5 \\
$\mathbf{M g}$ & 20,5 & 12,9 \\
$\mathbf{C a}$ & 1,3 & 38,3 \\
\hline
\end{tabular}

\subsection{Determinação da amorfização por difração de raios $X$}

O material obtido foi analisado por difração de raios $X$ para determinar a amorfização do mesmo. Não foram observados picos indicando a presença de fases cristalinas, somente halos característico de materiais amorfos tanto para 
o pó de vidro (figura 9) quanto para as microesferas (figura 10). Após o processo de esferolização o material se mantém amorfo.

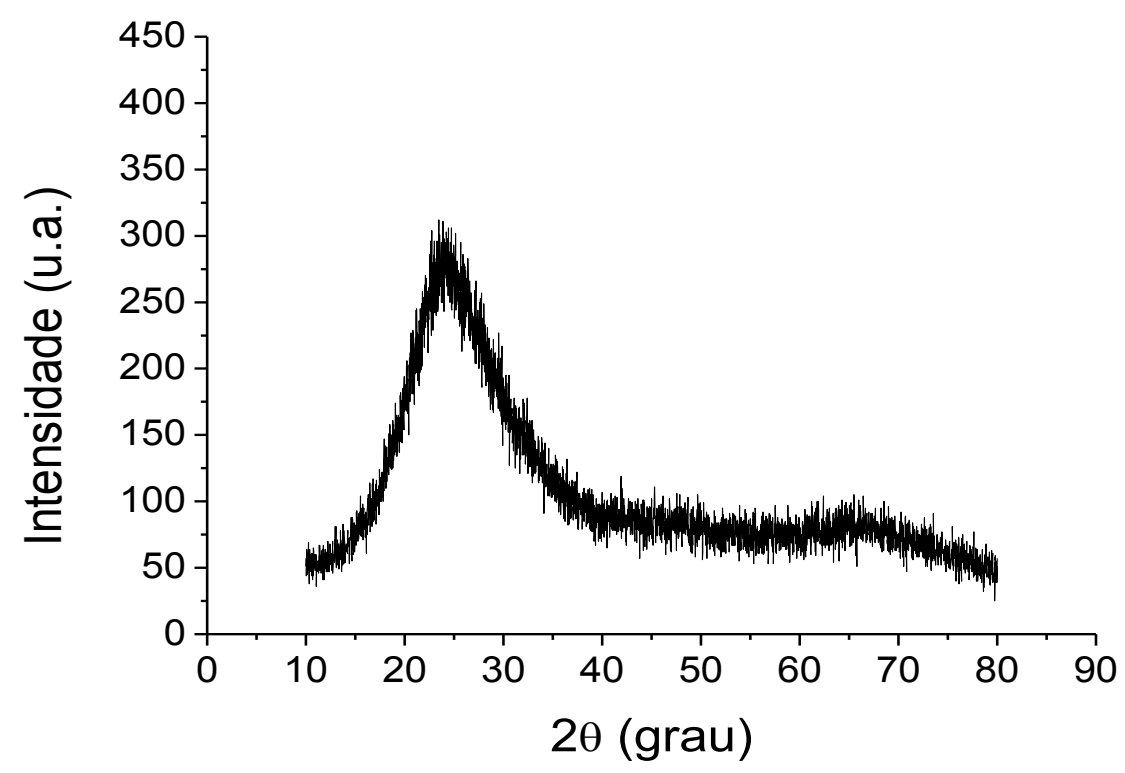

FIGURA 9: Difratograma de raios $\mathrm{X}$ do pó de vidro.

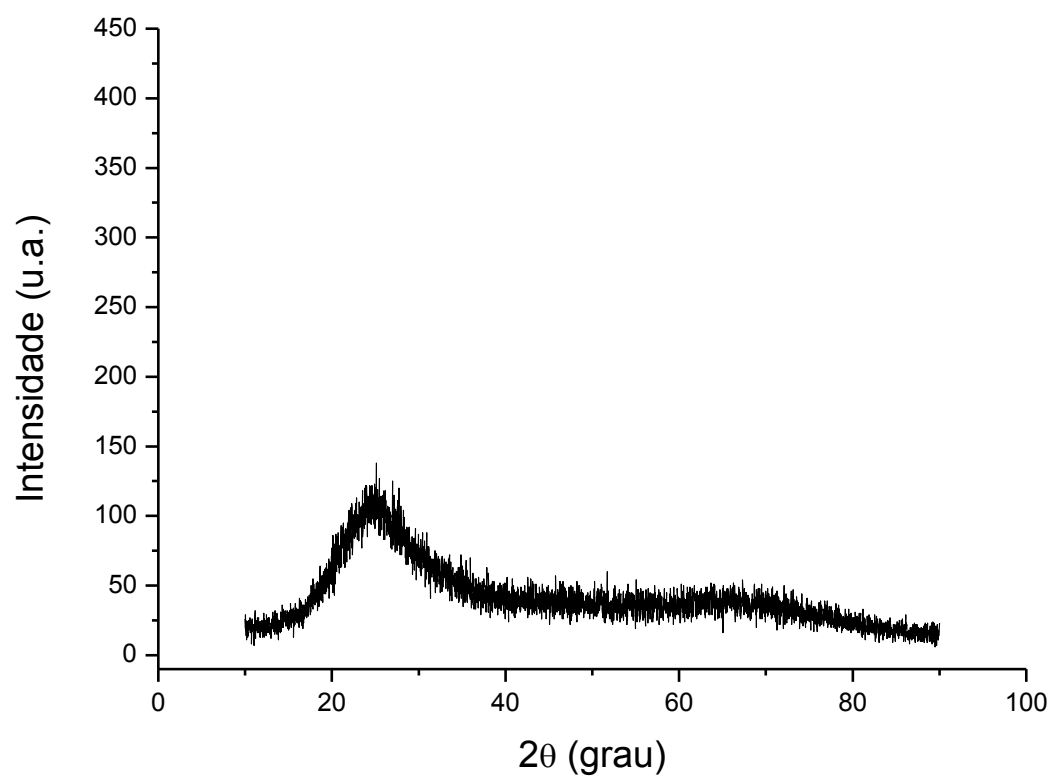

FIGURA 10: Difratograma de raios $X$ das microesferas vítreas.

Esses resultados obtidos para o pó de vidro e para as microesferas demonstraram a possibilidade de utilizar o método da esferolização para 
obtenção de microesferas da composição de interesse para este estudo, com tamanho e formato regulares e controlados já que não há alteração no arranjo atômico e o material continua no estado vítreo.

\subsection{Análises Térmicas}

\subsubsection{Calorimetria exploratória diferencial: Microesferas}

A figura 11 mostra a curva de DSC, da referência onde vidros aluminossilicatos foram estudados para aplicação em radioterapia interna seletiva [18], onde pode ser observada a transição vítrea em $825^{\circ} \mathrm{C}$ e a mudança na linha base de $920^{\circ} \mathrm{C}$ a $1000^{\circ} \mathrm{C}$.

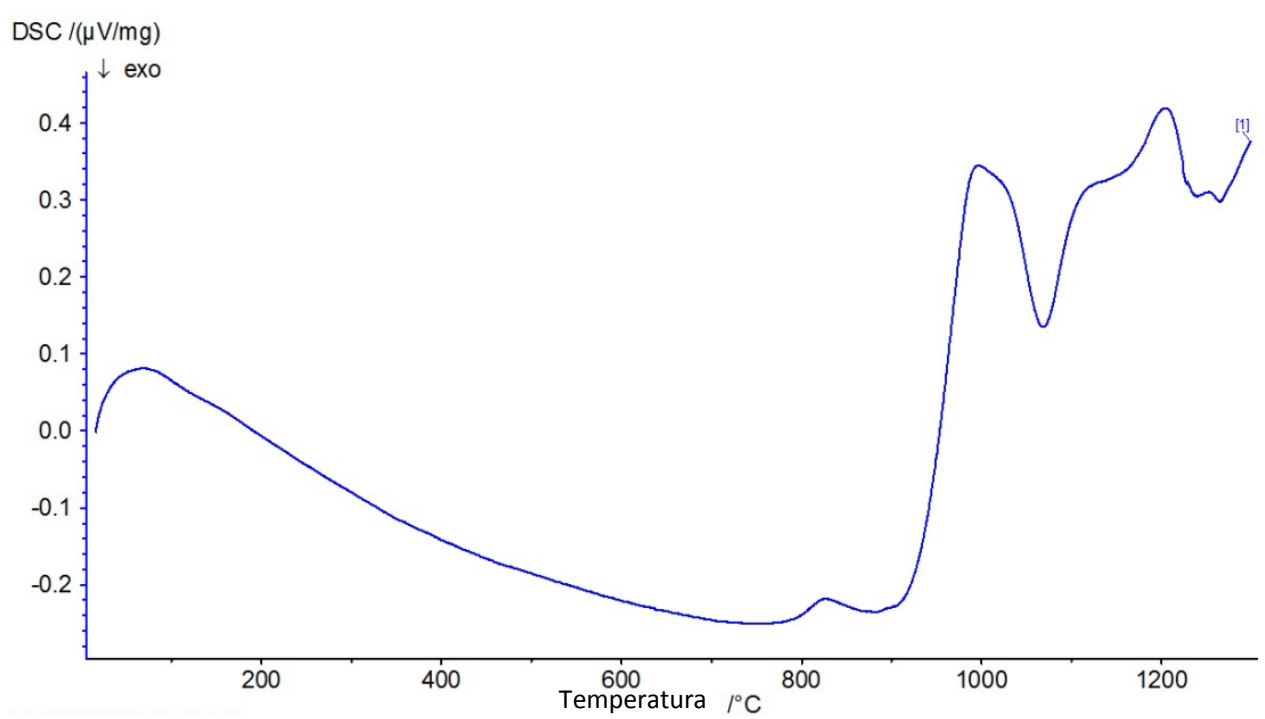

FIGURA 11: Curva DSC de um vidro aluminossilicato contendo 5\% de hólmio em mol (taxa de aquecimento: $10^{\circ} \mathrm{C} / \mathrm{min}$. Atmosfera: ar sintético) [18].

Foi feita uma medida de DSC das microesferas produzidas para comparação com a referência (figura 11). O resultado é mostrado na figura 12. A medida foi realizada em atmosfera dinâmica de ar sintético, em um cadinho de alumina a $10^{\circ} \mathrm{C} / \mathrm{min}$, assim como a análise da referência. A transição vítrea foi observada em $807^{\circ} \mathrm{C}$ e a mudança na linha base ocorreu de $907^{\circ} \mathrm{C}$ a $990^{\circ} \mathrm{C}$. $O$ vidro utilizado tem composição igual à composição da referência, exceto pela ausência do hólmio destinado a aplicação para tratamento de CHC. A mudança na linha base entre a transição vitrea e a cristalização é um processo que não é observado em curvas típicas de DSC para sistemas amorfos. 


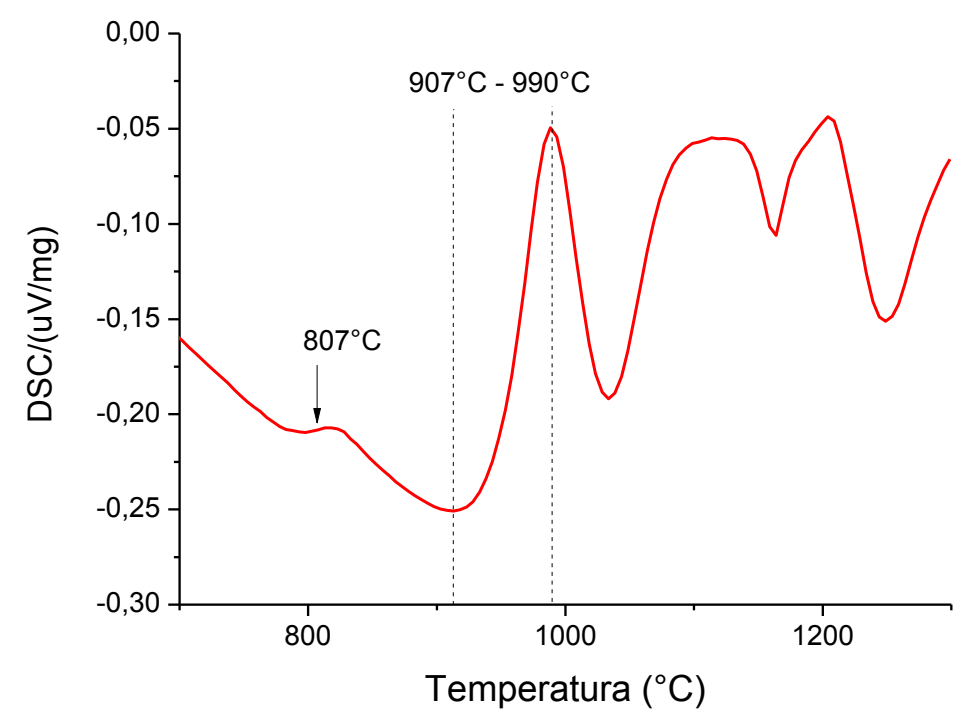

FIGURA 12: Curva DSC das microesferas vítreas (taxa de aquecimento: $10^{\circ} \mathrm{C} / \mathrm{min}$. Atmosfera: ar sintético).

A figura 13 mostra uma micrografia retirada da referência [18], onde as microesferas foram aquecidas até $950^{\circ} \mathrm{C}$ e resfriadas. É possível observar a formação de pescoços, característicos do processo de sinterização por fluxo viscoso.

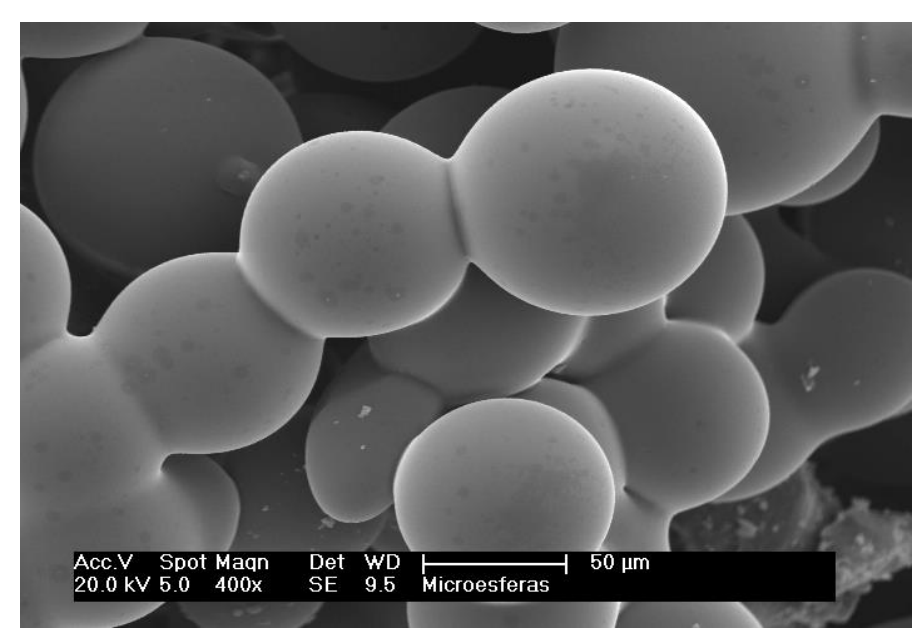

FIGURA13: Imagem de MEV de microesferas de vidro aluminossilicato, contendo $5 \%$ de hólmio em mol, após aquecimento a $950^{\circ} \mathrm{C}$ [18]. 


\subsubsection{Calorimetria exploratória diferencial: pó de vidro e monolito}

A figura 14 apresenta as curvas das análises de calorimetria exploratória diferencial DSC no pó de vidro e em um monolito do vidro (um pedaço de vidro obtido a partir do vidro vertido em um molde de aço e pequeno o suficiente para que coubesse dentro do cadinho de análise) para comparação. A figura 15 mostra uma imagem parcial do sistema DSC, focalizando os cadinhos de análise e referência com a amostra monolítica antes da análise. As análises foram realizadas em atmosfera dinâmica de ar sintético, em cadinhos de alumina a $10^{\circ} \mathrm{C} / \mathrm{min}$.

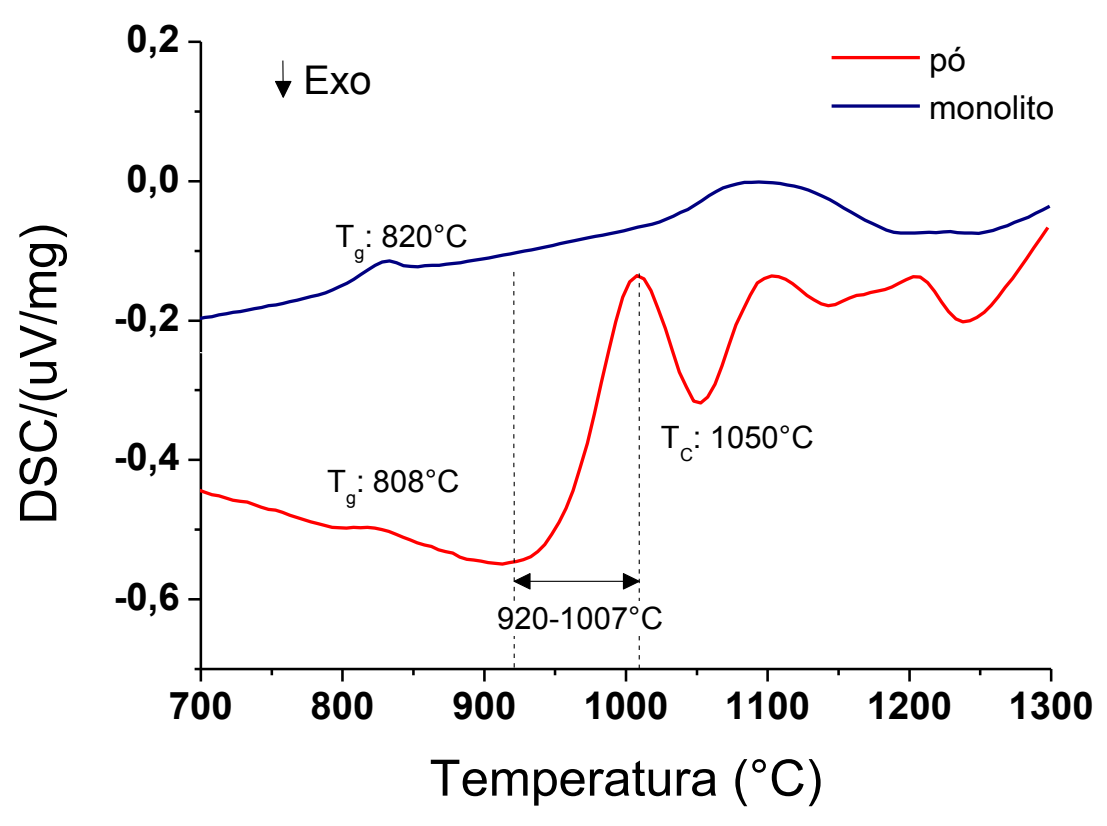

FIGURA 14: Curvas de calorimetria exploratória diferencial de amostras do vidro em pó solto e em um monólito. A temperatura de transição (Tg) vítrea foi determinada na faixa de $808-820^{\circ} \mathrm{C}$. As análises foram realizadas em atmosfera de ar sintético dinâmico, com velocidades de aquecimento de $10^{\circ} \mathrm{C} / \mathrm{min}$ em cadinhos de alumina. 


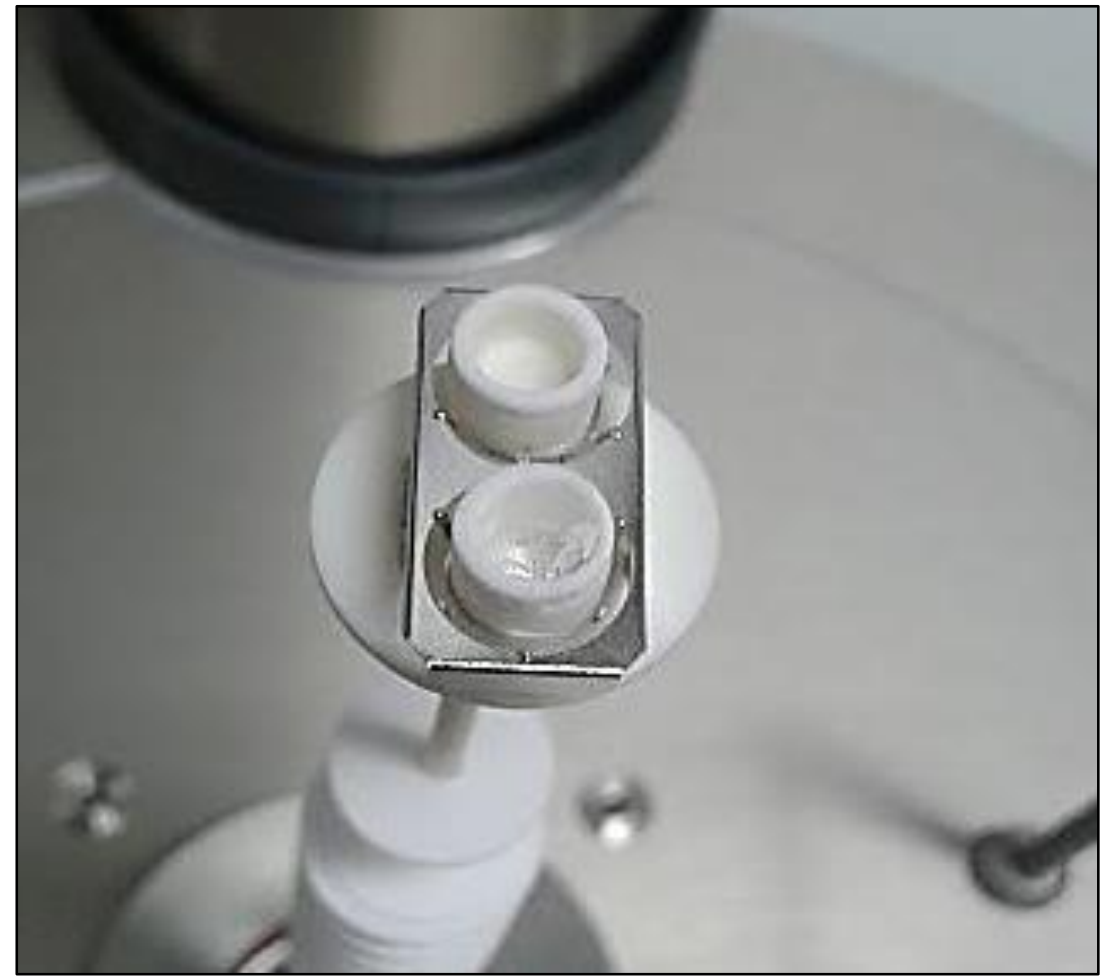

FIGURA 15: Imagem parcial do sistema DSC, focalizando o cadinho com a amostra monolítica e o cadinho de referência. Ambos cadinhos são de alumina.

Nas curvas de DSC é possível observar a transição vítrea na faixa de $808-820^{\circ} \mathrm{C}$. Na curva do pó é possível observar uma mudança na linha base na faixa de $920^{\circ} \mathrm{C}$ a $1000^{\circ} \mathrm{C}$, seguida de um pico exotérmico associado a um processo de cristalização, como será confirmado posteriormente (temperatura de máximo de cristalização a $1050^{\circ} \mathrm{C}$ ). A mudança na linha base ocorre no material independente desse estar na forma de pó ou de microesferas. $\mathrm{Na}$ curva de DSC do material na forma monolítica, não se observa tanto a mudança na linha base como a cristalização. O fenômeno de cristalização não é observado nesta curva, pois a cristalização ocorre predominantemente na superfície do material e quando na forma de pó, o material apresenta uma área superficial específica muito maior do que 0 monolito, possibilitando 0 aparecimento de um pico exotérmico referente à cristalização superficial muito mais intenso.

A figura 16 mostra a fotografia de um cadinho com a pastilha dentro logo após o resfriamento do sistema. É possível observar a retração da amostra em 
relação ao tamanho do cadinho e a formação de uma pastilha que não aderiu ao cadinho e pôde ser facilmente removida. Assim, propomos que a mudança na linha base esteja associada à sinterização e vinculada à área superficial de contato entre as partículas e o porta amostra utilizado na análise, devido a retração do material durante a sinterização. Como evidência de tal fenômeno, não é esperada uma mudança na linha base na curva de DSC da amostra monolítica na mesma faixa de temperatura sob as mesmas condições, como efetivamente observado.

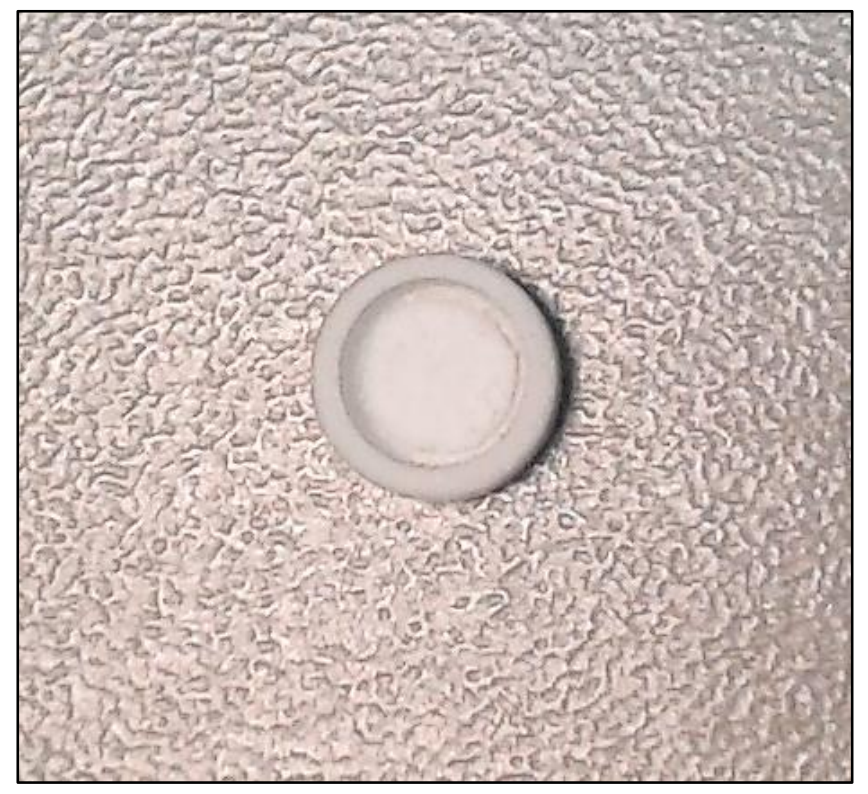

FIGURA 16: Imagem de uma pastilha formada dentro de um cadinho após uma análise de DSC. É possível observar a retração da pastilha dentro do cadinho.

A partir destes resultados e dos observados na referência [18] decidiu-se investigar em mais detalhes a sinterização do vidro. Foram realizadas diversas análises de DSC variando alguns fatores como ciclagem térmica, material do cadinho e material do vidro.

\subsubsection{Análises de DSC subsequentes}

A figura 17 apresenta as curvas de DSC de uma amostra aquecida inicialmente a $1000^{\circ} \mathrm{C}$, onde se observa o final da mudança na linha base. $\mathrm{O}$ material foi então resfriado até a temperatura ambiente e reaquecido até 
$1300^{\circ} \mathrm{C}$. Na última etapa, a curva de DSC não apresenta a mudança na linha base, indicando que esta está associada ao processo de sinterização e não se repete tendo em vista que o processo de sinterização já foi concluído e a pastilha já está formada. As análises foram realizadas em atmosfera de ar sintético dinâmico, velocidade de aquecimento de $10^{\circ} \mathrm{C} / \mathrm{min}$ em cadinho de alumina.

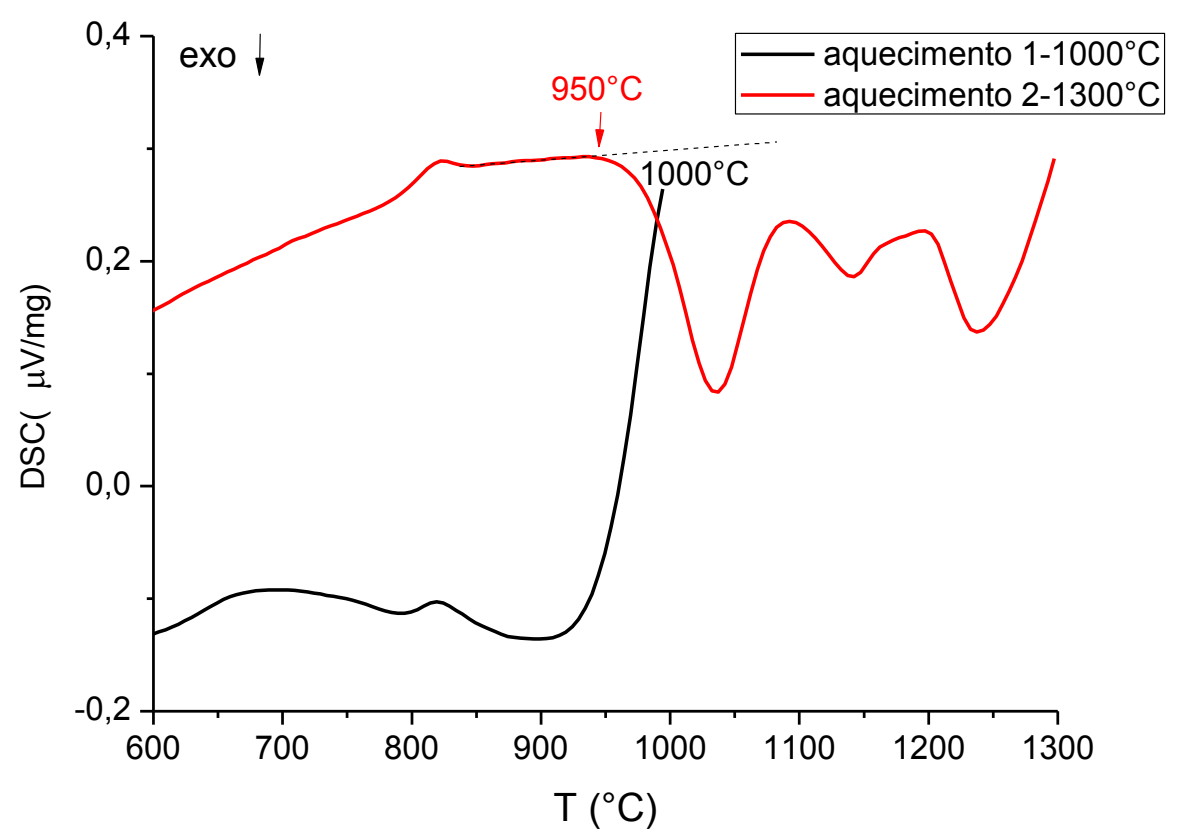

FIGURA 17: Curvas de DSC de amostras do vidro na forma de pó em duas etapas: aquecimento até $1000^{\circ} \mathrm{C}$, com posterior resfriamento até a temperatura ambiente, e reaquecimento até $1300^{\circ} \mathrm{C}$. As análises foram realizadas em atmosfera de ar sintético dinâmico, velocidade de aquecimento de $10^{\circ} \mathrm{C} / \mathrm{min}$ em cadinho de alumina. Foi inserida uma linha pontilhada acompanhando a linha base para melhor visualização do início do pico de cristalização em $950^{\circ} \mathrm{C}$.

\subsubsection{Curvas Isotermas de DSC}

No intuito de avaliar a correlação entre o evento endotérmico e a sinterização, foram obtidas curvas isotérmicas de DSC (figura 18) a partir de determinadas temperaturas: $900^{\circ} \mathrm{C}, 920^{\circ} \mathrm{C}$ e $950^{\circ} \mathrm{C}$. Em cada análise a amostra foi aquecida até a temperatura de tratamento isotérmico a $10^{\circ} \mathrm{C} / \mathrm{min}$ em cadinhos de alumina. Observa-se que há um decaimento do sinal de DSC 
em função do tempo com taxas diferentes para cada temperatura, corroborando que se trata de um fenômeno de sinterização.

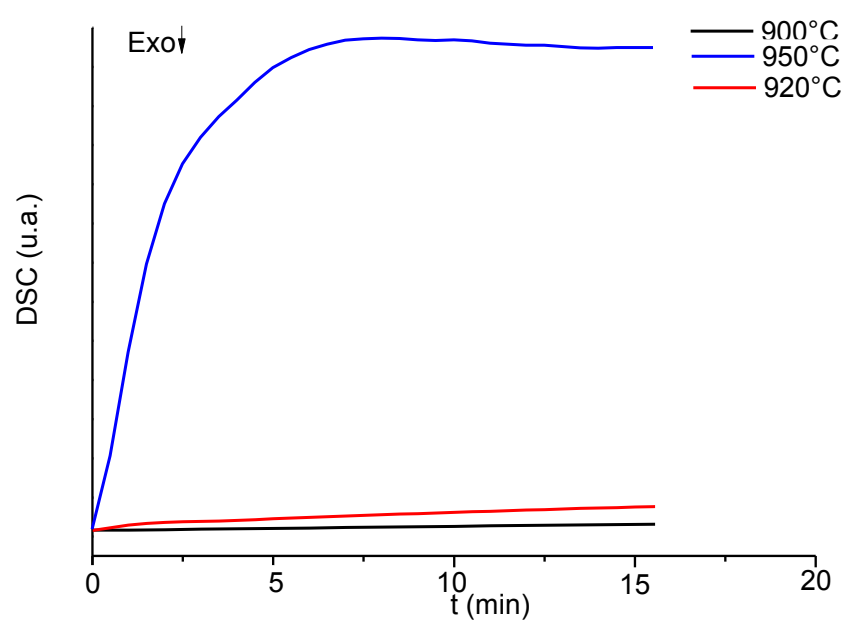

FIGURA 18: Curvas isotérmicas de DSC. Atmosfera de ar sintético em cadinhos de alumina.

\subsubsection{Resultados de DSC com cadinho de platina}

Foi também realizada uma análise de DSC do material particulado sob as mesmas condições utilizando um cadinho de platina ao invés de alumina, e a mudança na linha base atribuída à sinterização não foi observada com a mesma intensidade quanto nas análises em que se utilizaram cadinhos de alumina (figura 19) (embora tenham sido observadas mudanças microestruturais características da evolução do processo de sinterização, por microscopia eletrônica de varredura). Uma possível explicação é que, no porta amostra do equipamento de DSC, a transferência de energia é realizada na interface do material com a base do cadinho. Durante o processo de sinterização a amostra retrai, reduzindo a superfície de contato e gerando um sinal correspondente a mudança da linha base na direção endotérmica, embora a sinterização seja reconhecida como um fenômeno exotérmico. Como a alumina apresenta um coeficiente de condutibilidade térmica na faixa de 16-31 
W/m.K [42] e a platina $72 \mathrm{~W} / \mathrm{m} . \mathrm{K}$ [43], a condução do calor na platina é muito mais rápida, permitindo a difusão da energia por todo o cadinho.

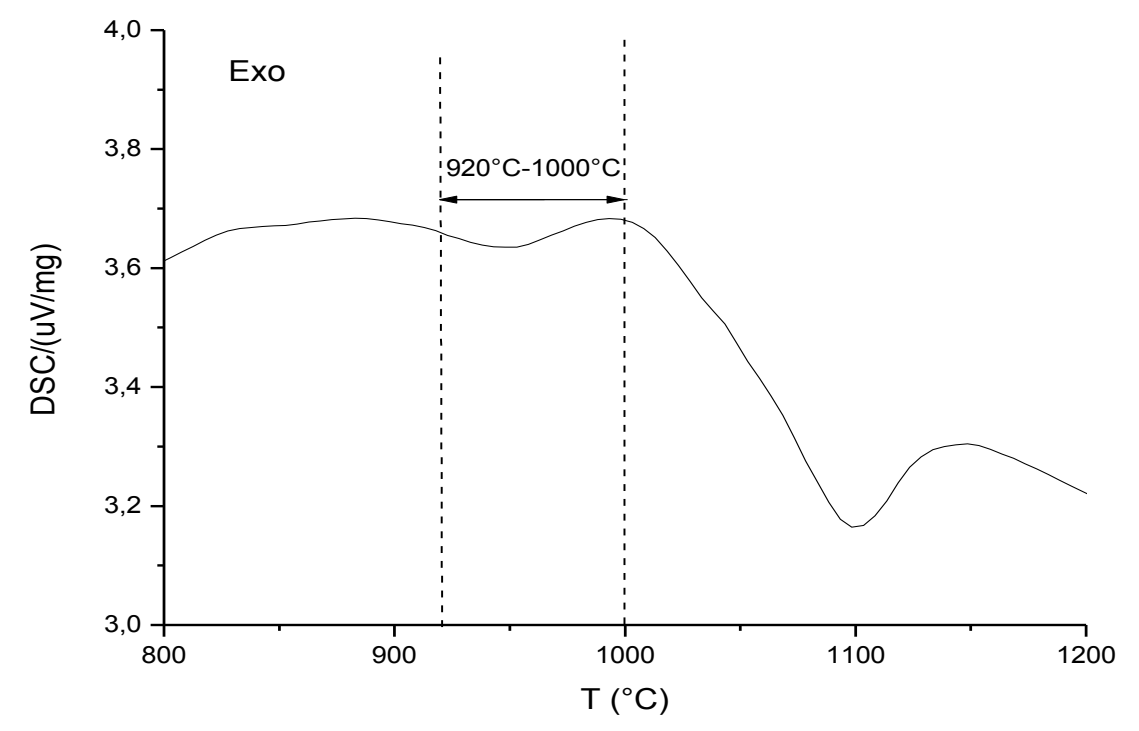

FIGURA 19: Curva de DSC do material em ar sintético, a $10^{\circ} \mathrm{C} / \mathrm{min}$ em um cadinho de platina.

A figura 20 apresenta uma análise de DSC do pó de vidro solicitada à empresa Netzsch. O objetivo, neste caso, foi comparar a análises realizadas no laboratório de vidros e compósitos do IPEN (LAVICOM) em um cadinho de platina com análises em um forno com um melhor controle de temperatura, visando diminuir os efeitos da linha base. A análise foi feita em um cadinho de platina sob atmosfera de argônio em um forno de platina. Na curva obtida a mudança na linha base associada ao processo de sinterização não é intensa o suficiente para ser observada. A temperatura de transição vítrea foi identificada em $795,8^{\circ} \mathrm{C}$. 


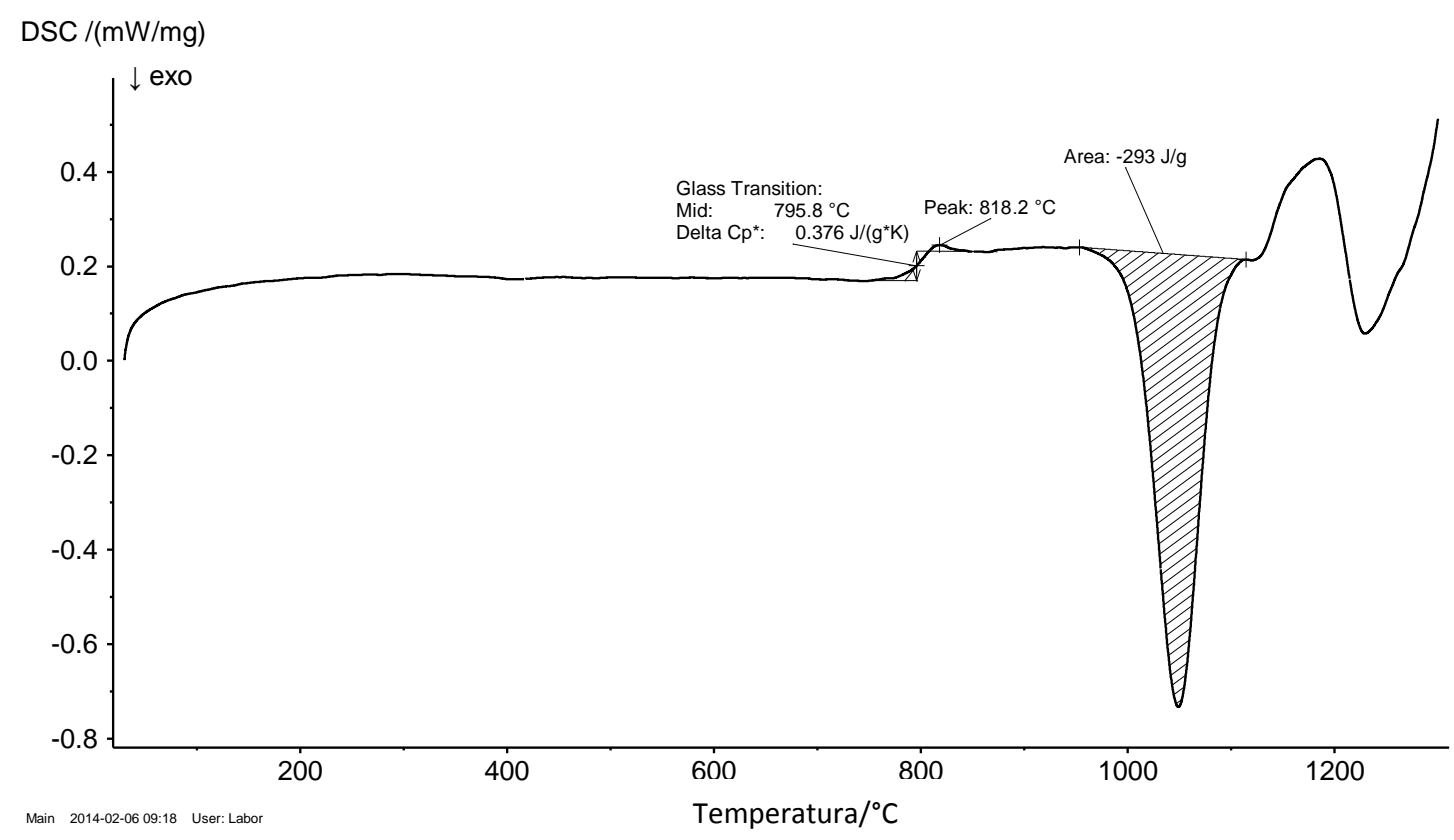

FIGURA 20: Curva de DSC do material analisado em atmosfera de argônio, a $10^{\circ} \mathrm{C} / \mathrm{min}$ em um cadinho de platina. A análise foi realizada pela empresa Netzsch em um forno de platina.

\subsubsection{Resultados de DSC em diferentes vidros}

A figura 21 mostra a curva de DSC de um vidro fosfato analisado no laboratório cujos resultados estão em vias de publicação. A composição do vidro é 44,3 $\mathrm{P}_{2} \mathrm{O}_{5} .38,0 \mathrm{SiO}_{2} .17,3 \mathrm{Al}_{2} \mathrm{O}_{3} .0,4 \mathrm{Lu}_{2} \mathrm{O}_{3}$ em \%mol. Apesar de ter uma composição totalmente distinta é possível observar uma mudança na linha base de 890 a $1055^{\circ} \mathrm{C}$ após a transição vítrea em $750^{\circ} \mathrm{C}$. A figura 22 mostra a imagem da pastilha formada no cadinho após a análise do vidro fosfato. Assim como o vidro estudado no presente trabalho o vidro formou uma pastilha que retraiu devido a sinterização. Outros vidros estudados no laboratório que amoleceram por todo o cadinho não apresentaram a mudança na linha base. 


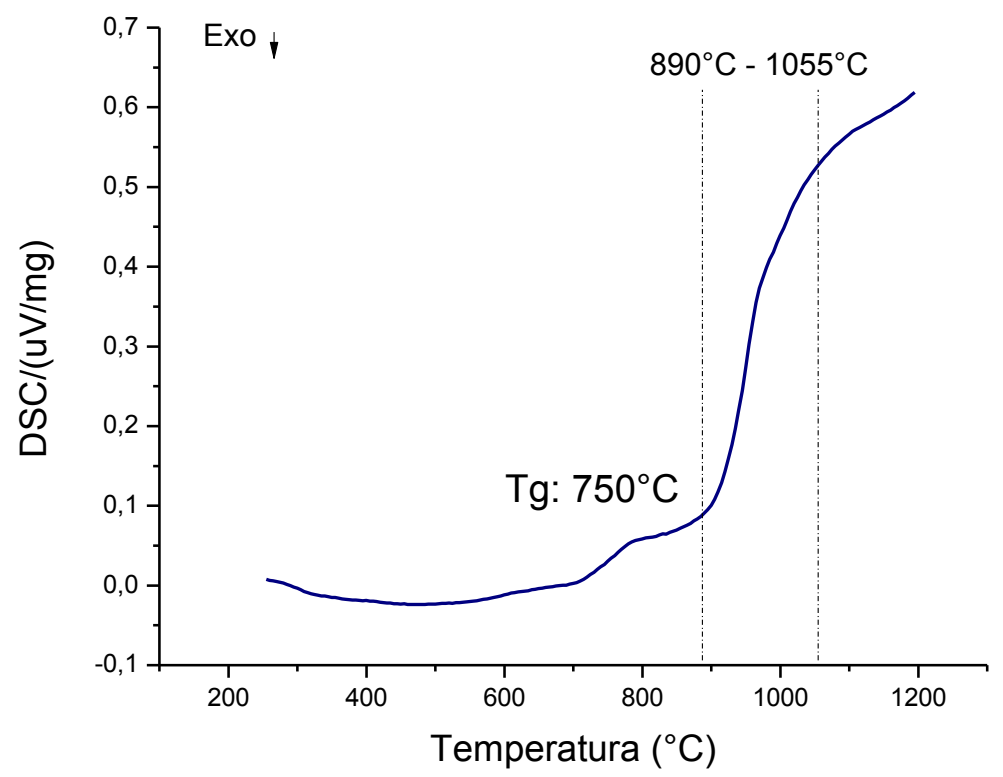

FIGURA 21: Curva de DSC de um vidro fosfato, analisado em atmosfera de ar sintético, a $10^{\circ} \mathrm{C} / \mathrm{min}$ em um cadinho de alumina.

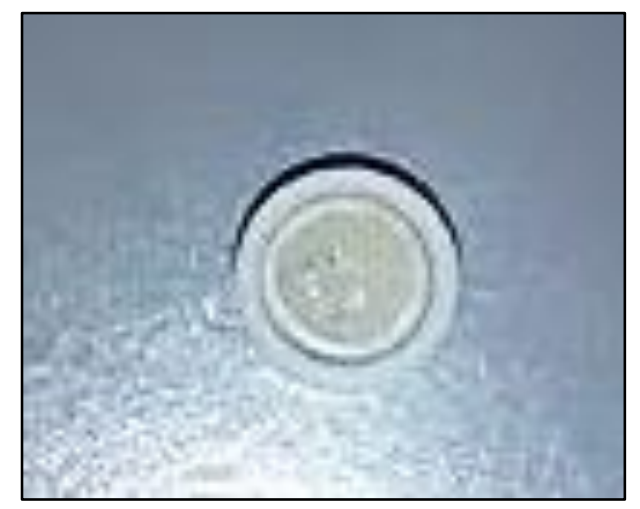

FIGURA 22: Imagem de uma pastilha formada dentro de um cadinho após uma análise de DSC de um vidro fosfato estudado no laboratório. É possível observar a retração da pastilha dentro do cadinho.

Estes resultados sustentam a hipótese de sinterização do vidro durante a análise térmica, embora o fenômeno seja observado com intensidades diferentes dependendo das condições experimentais. Além disso, estes resultados mostram que esse fenômeno também é observado em outros vidros, não sendo uma característica particular do sistema em estudo. 
$\mathrm{Na}$ sequência foram realizados experimentos variando alguns parâmetros que podem alterar as medidas de DSC tais como: taxa de aquecimento, tamanho de partículas e atmosfera de medida.

\subsubsection{Resultados de DSC em diferentes taxas de aquecimento}

Para verificar a influência da taxa de aquecimento nas análises de DSC, foi realizada uma medida a $20^{\circ} \mathrm{C} / \mathrm{min}$ ao invés de $10^{\circ} \mathrm{C} / \mathrm{min}$ como as outras análises (figura 23). A mudança na linha base e o pico de cristalização ocorreram na análise a $20^{\circ} \mathrm{C} / \mathrm{min}$ na faixa de $936^{\circ} \mathrm{C}$ a $1014^{\circ} \mathrm{C}$ e a $1090^{\circ} \mathrm{C}$, em atraso em relação a análise a $10^{\circ} \mathrm{C} / \mathrm{min}$ que ocorreu na faixa de $917^{\circ} \mathrm{C}$ a $1000^{\circ} \mathrm{C}$ e a $1050^{\circ} \mathrm{C}$, fortalecendo a hipótese de que a mudança na linha base se trata do processo de sinterização por fluxo viscoso pois eventos de cinética mais lenta, assim como o processo de sinterização por fluxo viscoso, quando analisados em taxas mais rápidas são deslocados para a direita [35].

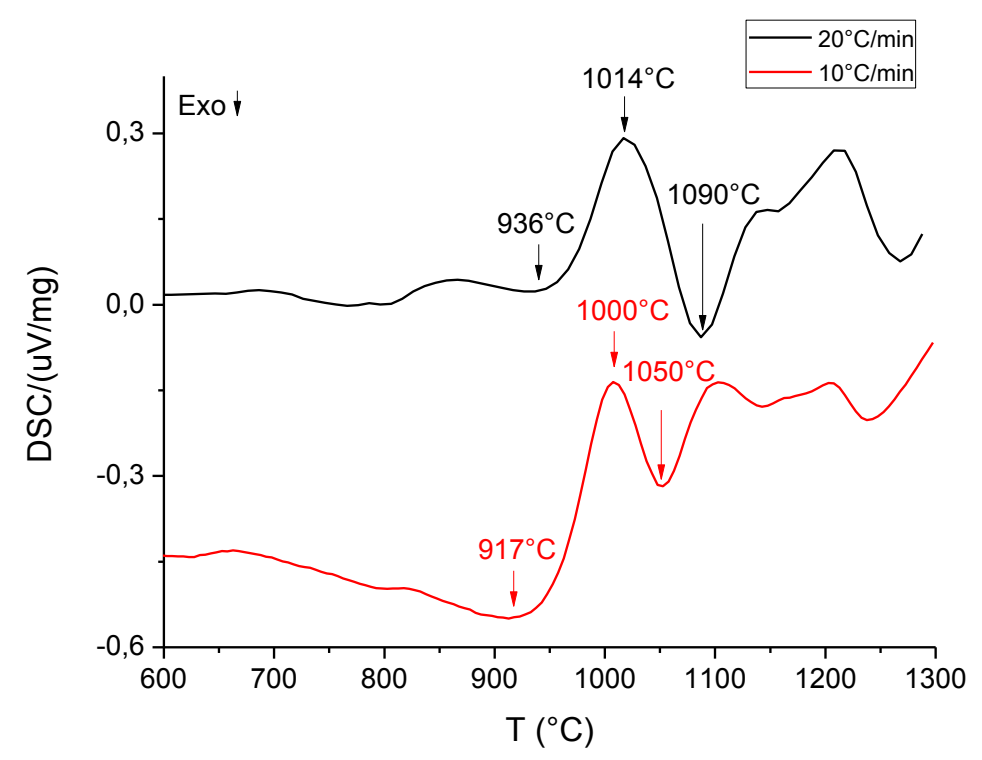

FIGURA 23: Curvas de DSC do material em ar sintético, a $10^{\circ} \mathrm{C} / \mathrm{min}$ e a $20^{\circ} \mathrm{C} /$ min em cadinhos de alumina. 


\subsubsection{Resultados de DSC em diferentes granulometrias}

Com o intuito de avaliar o efeito do tamanho de partículas na mudança na linha base estudada foi feita uma medida de DSC do mesmo material peneirado abaixo de $25 \mu \mathrm{m}$. A figura 24 mostra a comparação entre as curvas do material com granulometria abaixo de $25 \mu \mathrm{m}$ e na faixa de 45 a $63 \mu \mathrm{m}$. A mudança na linha base e o pico de cristalização ocorreram previamente para o material com menor granulometria, reforçando a hipótese que a mudança na linha base ocorre devido ao processo de sinterização por fluxo viscoso.

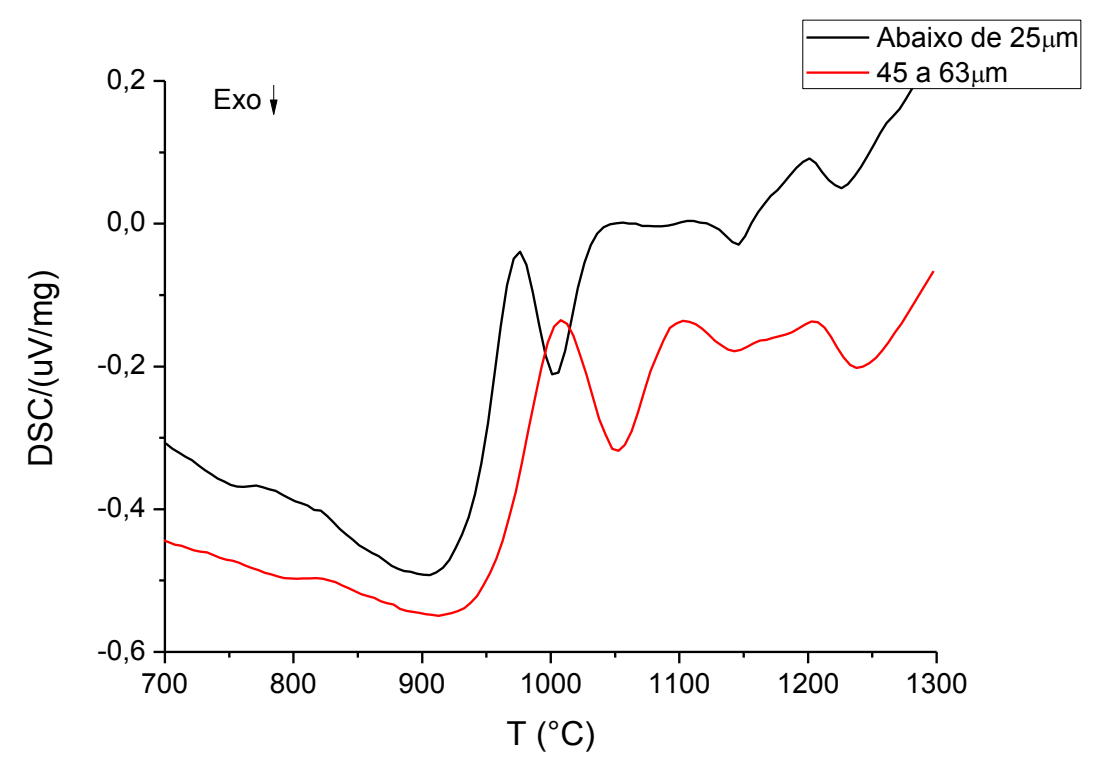

FIGURA 24: Curvas de DSC do material em ar sintético, a $10^{\circ} \mathrm{C} / \mathrm{min}$, em cadinhos de alumina, em duas faixas granulométricas: abaixo de $25 \mu \mathrm{m}$ e de 45 a $63 \mu \mathrm{m}$.

A sinterização por fluxo viscoso é um processo proporcional à area de superfície específica do material [31]. Quanto menor o tamanho das partículas, maior a área de superfície específica e menor a temperatura necessária para o início do processo de sinterização por fluxo viscoso. O mesmo ocorre para o processo de cristalização superficial. 


\subsubsection{Resultados de DSC em diferentes atmosferas}

Para avaliar possíveis efeitos da atmosfera de análise no evento observado foram feitas análises em atmosferas de argônio e nitrogênio, além do ar sintético previamente utilizado. As condições de temperatura e os cadinhos foram os mesmos em todas as análises. As curvas obtidas mostram os mesmos fenômenos nas mesmas temperaturas, inclusive a mudança na linha base estudada no presente trabalho. Portanto, é possível afirmar que o fenômeno observado não depende da atmosfera utilizada.

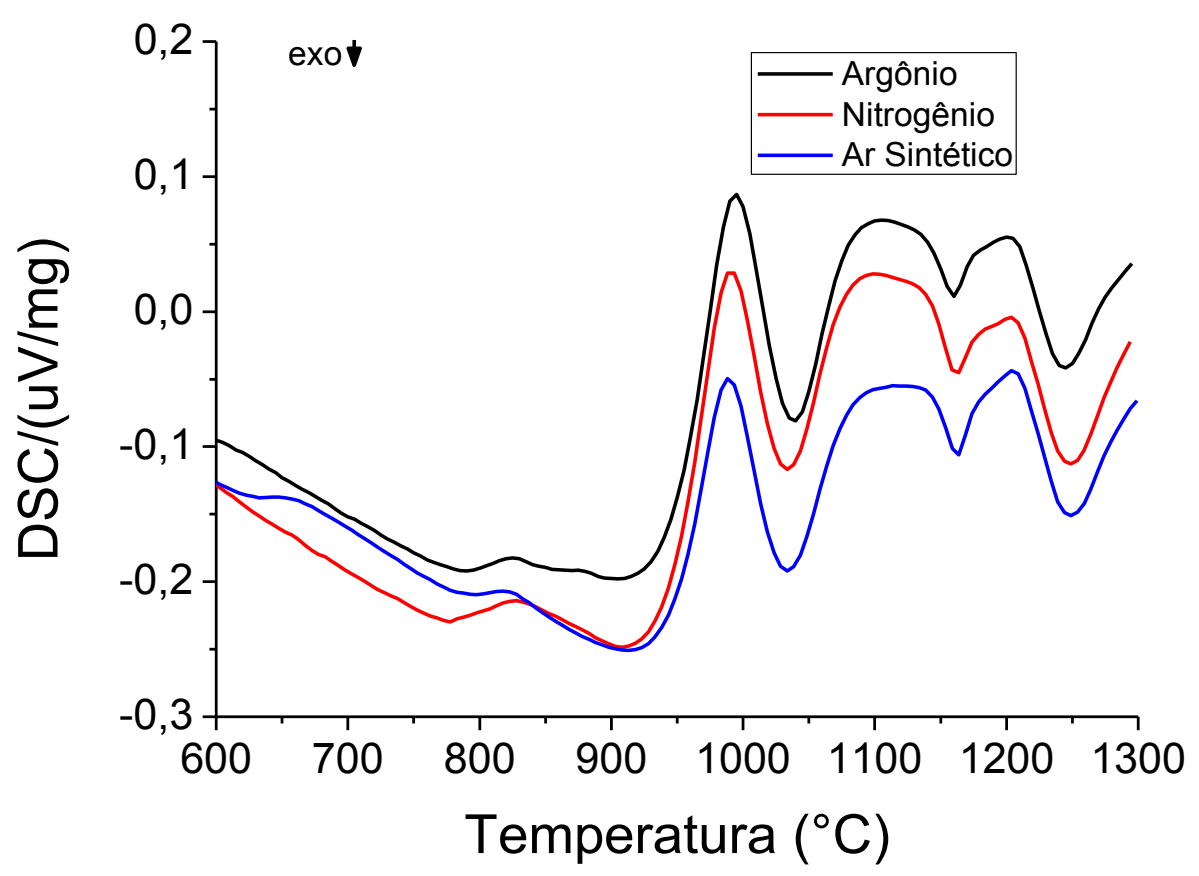

FIGURA 25: Curvas de análises de DSC realizadas em atmosferas distintas, a $10^{\circ} \mathrm{C} / \mathrm{min}$ em cadinhos de alumina.

\subsubsection{Comparação dos resultados de DSC e DTA}

Com o intuito de verificar a correlação da mudança na linha base observada com o fluxo de calor devido à retração da amostra durante a sinterização, foi realizada uma nova medida no mesmo equipamento utilizando a montagem para análise térmica diferencial (DTA), onde agora a medida é realizada na ponta de um termopar. A figura 26 mostra ambas as curvas. $\mathrm{Na}$ montagem de DSC a medida é realizada determinando-se o fluxo de calor transferido da superfície do cadinho para a amostra ao invés de ser 
concentrada em um único ponto. A figura 27 mostra um desenho esquemático de ambas as montagens.

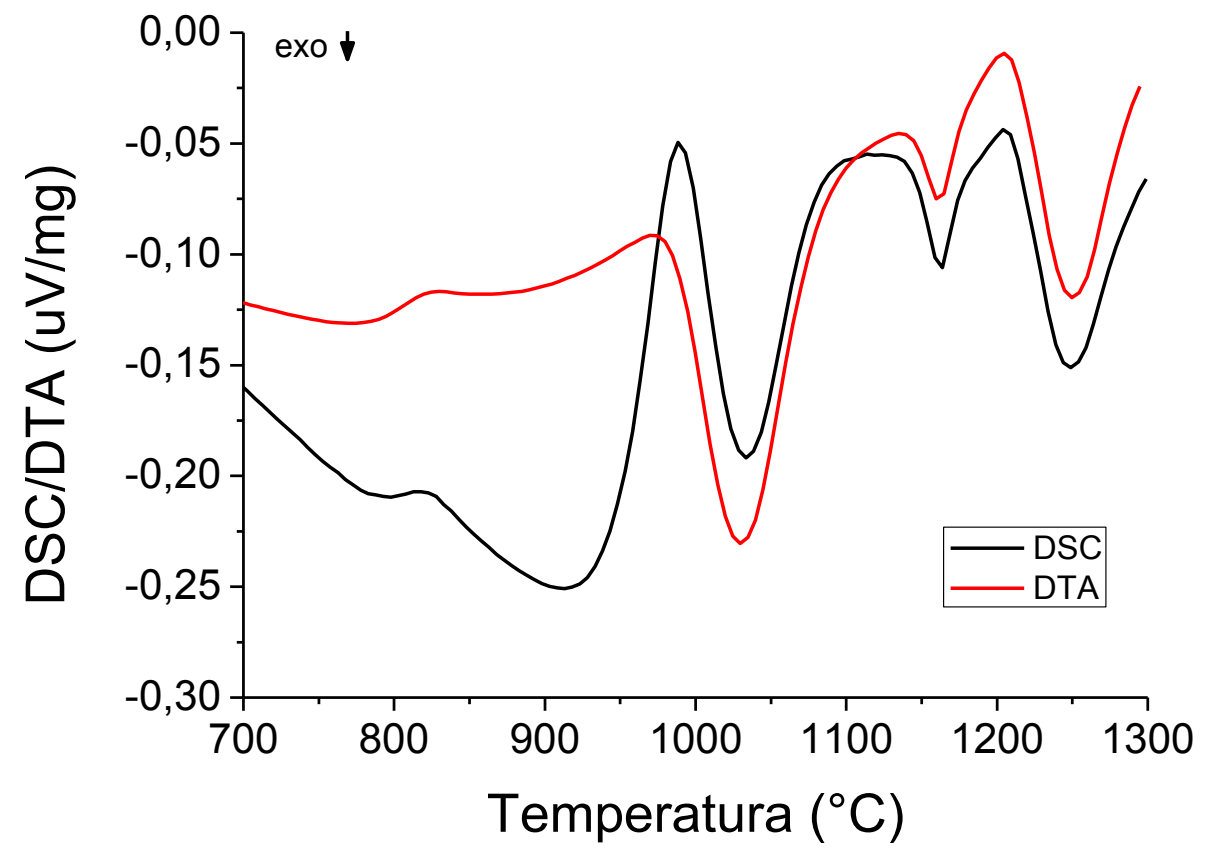

FIGURA 26: Curvas de DSC e DTA do material em atmosfera de ar sintético, a $10^{\circ} \mathrm{C} / \mathrm{min}$ em cadinhos de alumina.
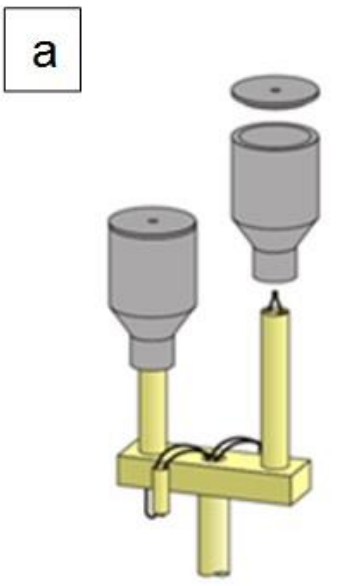
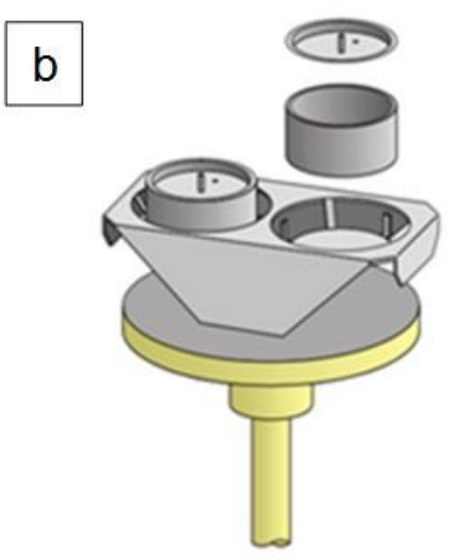

FIGURA 27: Desenho esquemático das montagens e cadinhos de a) DTA e b) DSC [44]. 
A intensa mudança na linha base não foi observada na curva de DTA indicando a relação do contato da superfície da amostra com o dispositivo de medida com a detecção da sinterização.

\subsubsection{Termogravimetria e espectrometria de massa}

A fim de verificar a variação de massa da amostra durante o processo de aquecimento foi realizada análise termogravimétrica (TG) (figura 28) em atmosfera de nitrogênio, a $10^{\circ} \mathrm{C} / \mathrm{min}$ em um cadinho de alumina simultaneamente com uma análise DTA até $1000^{\circ} \mathrm{C}$. Na análise de DTA assim como na figura 17 , foi observado o início do pico de cristalização em $955^{\circ} \mathrm{C}$. Assim como esperado, não houve uma variação de massa considerável durante todo o processo, mostrando que o fenômeno não está relacionado a perda ou ganho de massa. O equipamento para análise DTA foi acoplado a um espectrômetro de massa para determinar a composição de possíveis gases liberados durante a análise.

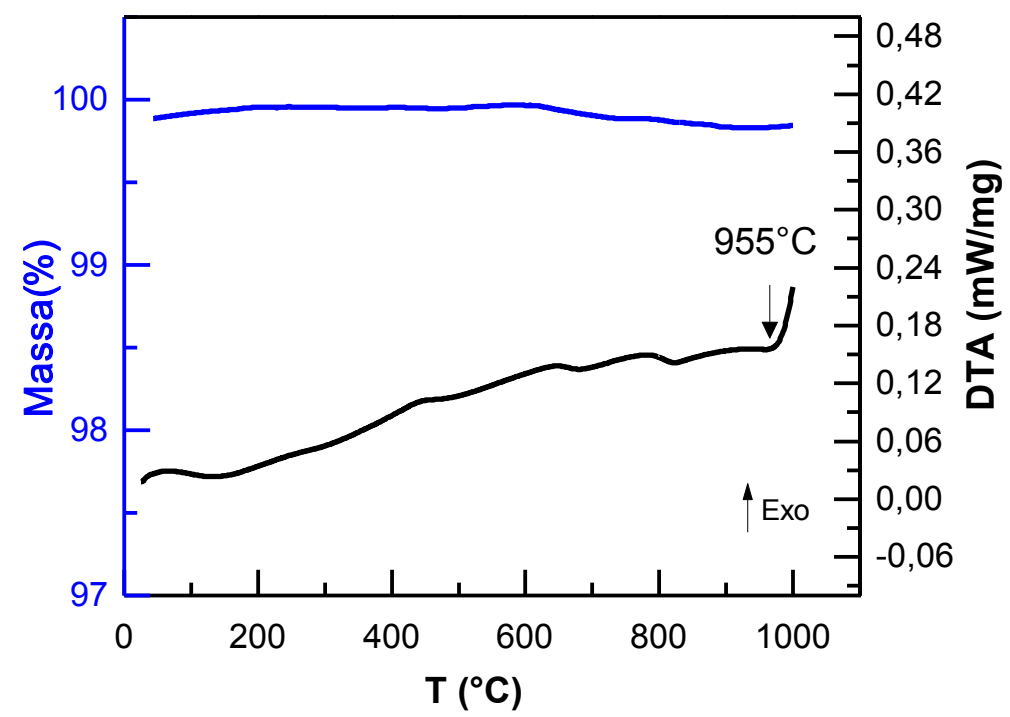

FIGURA 28: Curvas de análise termogravimetrica e DTA do material. A análise foi realizada em atmosfera de nitrogênio, a $10^{\circ} \mathrm{C} / \mathrm{min}$ em cadinho de alumina.

As figuras 29, 30 e 31 mostram a corrente iônica em função da temperatura para cada íon e molécula detectados na análise de espectrometria de massa acoplada ao DTA e à TG. Os gases monitorados foram $\mathrm{H}_{2} \mathrm{O}, \mathrm{CO}$ e 
$\mathrm{CO}_{2}$. As massas de cada íon e molécula monitoradas foram escolhidas a partir da base de dados NIST [45].

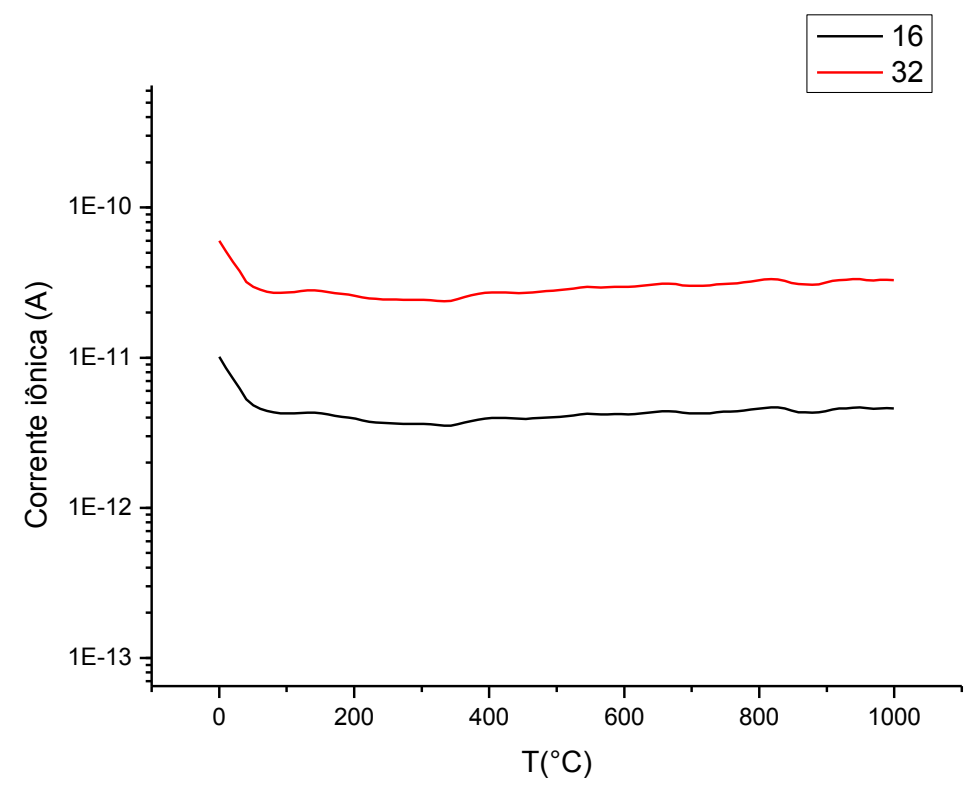

FIGURA 29: Curva de análise de espectrometria de massa para os íons de $\mathrm{O}_{2}$. Os números 16 e 32 são os valores das massas atômicas monitoradas.

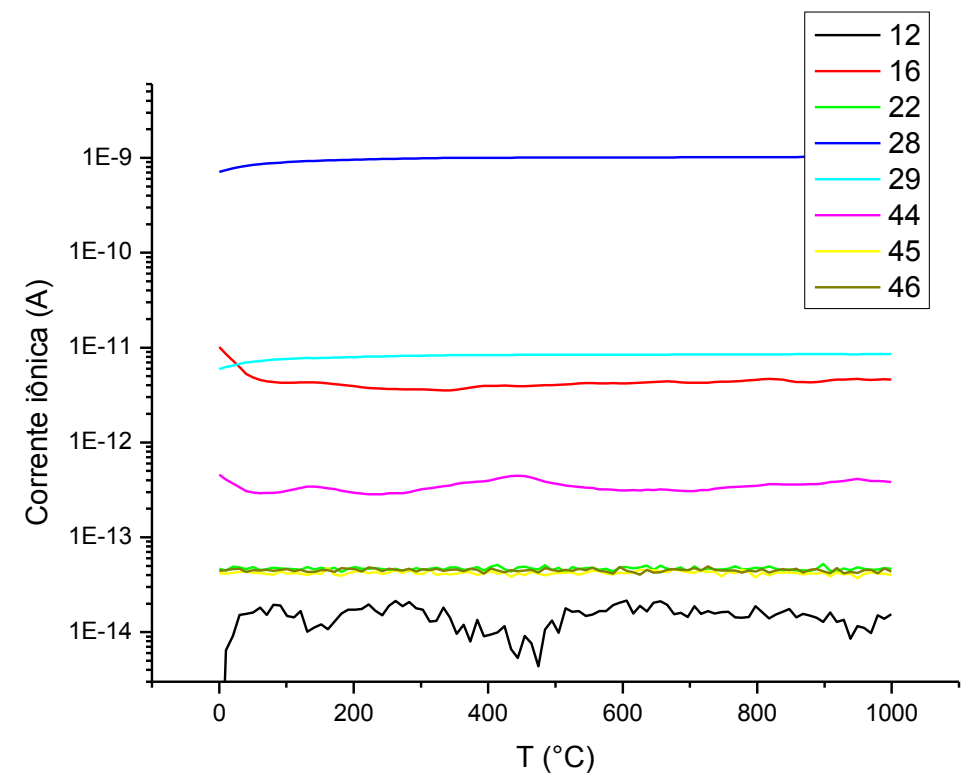

FIGURA 30: Curva de análise de espectrometria de massa para os íons de $\mathrm{CO}_{2}$. Os números $12,16,22,28,29,44,45$ e 46 são os valores das massas atômicas monitoradas. 


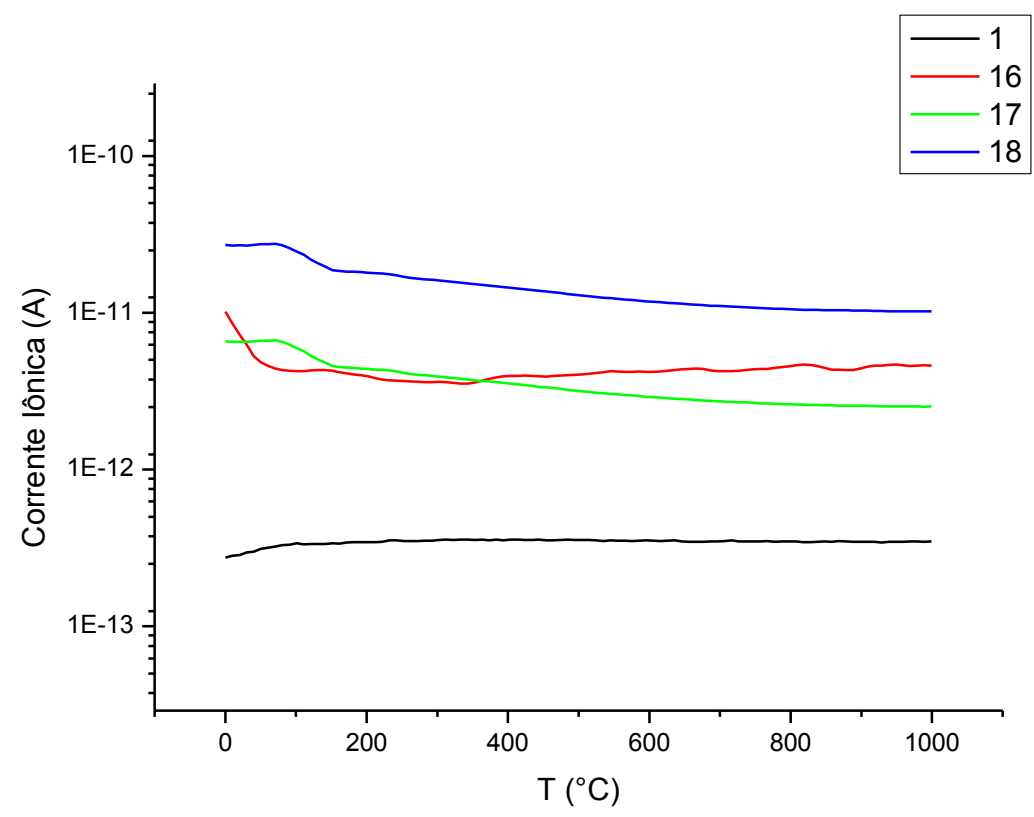

FIGURA 31: Curva de análise de espectrometria de massa para os íons de $\mathrm{H}_{2} \mathrm{O}$. Os números 1, 16, 17 e 18 são os valores das massas atômicas monitoradas.

Não se observou uma variação na corrente iônica relacionada à liberação de gases durante a análise, na faixa em que ocorre a mudança na linha base nas análises de DSC, o que reforça a proposta de que o fenômeno endotérmico está relacionado ao processo de sinterização de fluxo viscoso onde não há variação de massa ou liberação de gases.

\subsection{Caracterização das pastilhas após tratamento térmico}

Após as análises térmicas, o pó de vidro não aderiu ao cadinho e foram formadas pastilhas com dimensões da ordem de $4 \mathrm{~mm}$ de diâmetro que puderam ser retiradas facilmente do cadinho. Além disso, também foram produzidas pastilhas em um forno tubular simulando as condições das análises térmicas.

Nas micrografias das pastilhas obtidas na faixa de temperatura de 940$1000^{\circ} \mathrm{C}$ (figura 32) é possível observar que a sinterização está ocorrendo por meio da formação de pescoço na interface entre as partículas. A partir das 
micrografias com menor magnitude, foram medidos os diâmetros das pastilhas usando o software image $\mathrm{J}$.

Tendo em vista que não há variação de massa durante o processo de sinterização e o diâmetro inicial é o mesmo para todas as pastilhas. Cada diâmetro foi medido 5 vezes, a tabela 3 apresenta a média dos diâmetros medidos em função da temperatura e o desvio padrão. A redução no diâmetro com a temperatura ocorre devido ao processo de sinterização.
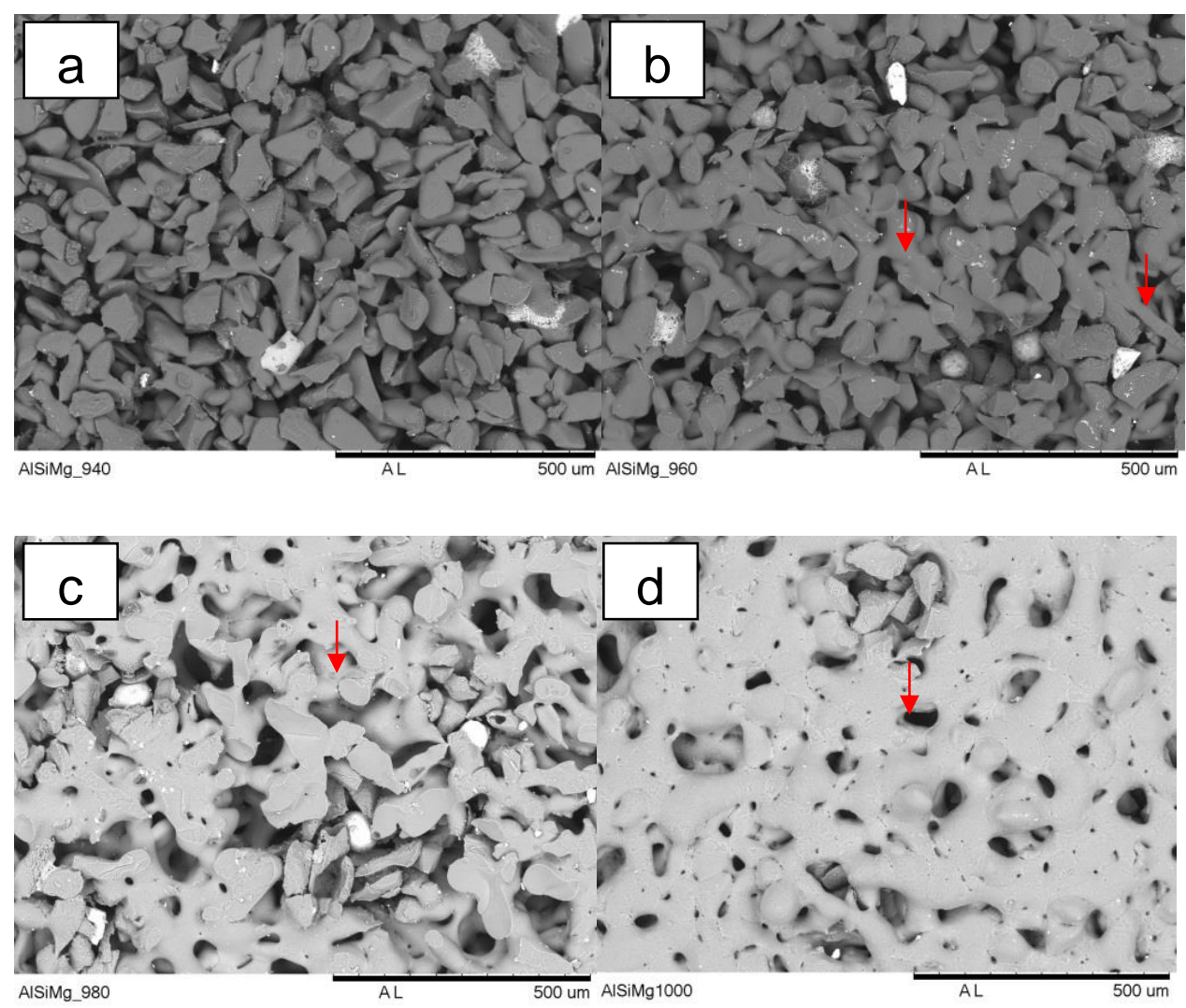

FIGURA 32: Micrografias das pastilhas obtidas a a) $940^{\circ} \mathrm{C}$, b) $960^{\circ} \mathrm{C}$, c) $980^{\circ} \mathrm{C}$ e d) $1000^{\circ} \mathrm{C}$. As setas vermelhas indicam a formação de pescoços entre as partículas. 
TABELA 3: Valores médios dos diâmetros medidos utilizando o software image J em função da temperatura e o desvio padrão.

\begin{tabular}{ccccc}
\hline Temperatura $\left({ }^{\circ} \mathbf{C}\right)$ & $\mathbf{9 4 0}$ & $\mathbf{9 6 0}$ & $\mathbf{9 8 0}$ & $\mathbf{1 0 0 0}$ \\
\hline diâmetro médio $(\mathbf{m m})$ & 4,25 & 4,13 & 3,94 & 3,87 \\
desvio padrão & 0,02 & 0,03 & 0,02 & 0,02 \\
\hline
\end{tabular}

As densidades das pastilhas tratadas termicamente a $960^{\circ} \mathrm{C}, 980^{\circ} \mathrm{C}$ e $1000^{\circ} \mathrm{C}$ foram determinadas por picnometria a He (tabela 4). Foi observado um aumento na densidade entre $960^{\circ} \mathrm{C}$ e $980^{\circ} \mathrm{C}$ e entre $980^{\circ} \mathrm{C}$ e $1000^{\circ} \mathrm{C}$ a densidade não variou. Os resultados observados não são compatíveis com os valores calculados a partir das micrografias, pois nestas o volume estimado é o volume aparente e na medida de picnometria, o gás He penetra pelos poros abertos e é medida a densidade real. A variação de densidade medida por picnometria está possivelmente associada ao processo de cristalização concomitante com o processo de sinterização.

TABELA 4: Valores de densidade determinada por picnometria a gás He.

\begin{tabular}{cccc}
\hline $\begin{array}{c}\text { Temperatura de } \\
\text { tratamento }\end{array}$ & $960^{\circ} \mathbf{C}$ & $980^{\circ} \mathbf{C}$ & $\mathbf{1 0 0 0 ^ { \circ } \mathbf { C }}$ \\
\hline $\begin{array}{c}\text { Densidade } \\
\left(\mathbf{g} / \mathbf{c m}^{3}\right)\end{array}$ & 2,39 & 2,57 & 2,54 \\
Desvio & 0,03 & 0,02 & 0,05 \\
\hline
\end{tabular}

A partir dos resultados obtidos das micrografias é possível afirmar que o volume da pastilha diminui linearmente na faixa de temperatura associada à mudança da linha base nas análises de DSC e este pode ser associado ao processo de sinterização por fluxo viscoso. 


\subsection{Cristalização concomitante com a sinterização}

Nas micrografias da figura 32 (c e d) foram observadas regiões com aparente porosidade indicando a ausência local do processo de sinterização por fluxo viscoso, provavelmente devido à cristalização do material. Nessas regiões o material apresenta uma cristalização superficial inibindo esse tipo de sinterização e provocando o aparecimento de poros. Na figura 17 é possível observar o início do processo de cristalização em $950^{\circ} \mathrm{C}$, abaixo da temperatura final da mudança da linha base, indicando que as regiões observadas correspondem ao início do processo de cristalização concomitante com o fenômeno de sinterização.

Foram obtidos difratogramas de raios $X$ das pastilhas tratadas em diferentes temperaturas para avaliar a existência de fases cristalinas. Na figura 34 observa-se que somente a partir de tratamentos térmicos a $980^{\circ} \mathrm{C}$, picos de difração relacionados a fases cristalinas estão presentes nos difratogramas.

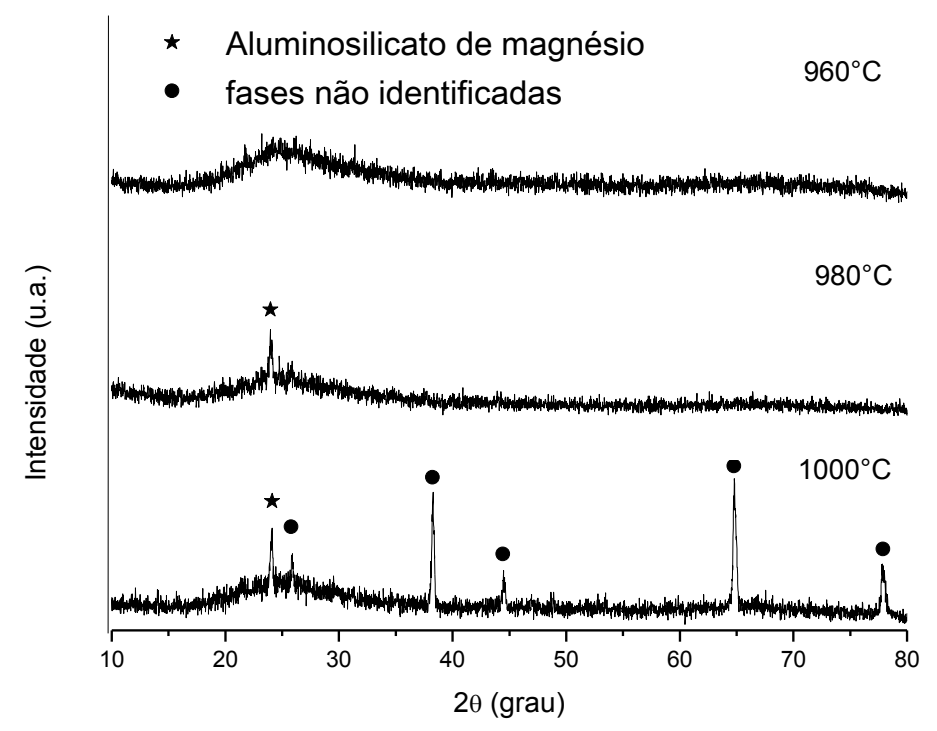

FIGURA 33: Difratogramas de raios $\mathrm{X}$ das pastilhas tratadas termicamente a $960^{\circ} \mathrm{C}, 980^{\circ} \mathrm{C}$ e $1000^{\circ} \mathrm{C}$.

Para identificação das fases foi utilizado o software Crystallographica Search-Match. Foi identificada a fase de aluminossilicato de magnésio em 
$980^{\circ} \mathrm{C}$, e as outras fases não foram identificadas sendo considerados os constituintes do material (figura 33).

O início de observação dos picos de cristalização coincide com a temperatura onde a densidade passa a ser praticamente constante. Isso ocorre pois a retração do material na forma cristalina e na forma vítrea apresentam coeficientes diferentes. Ao cristalizar, o material passa por fases intermediárias que possuem diferentes densidades.

\subsection{Comportamento do material após sinterização}

Para avaliar o comportamento de densificação do material, estendeu-se o tratamento térmico das pastilhas até $1200^{\circ} \mathrm{C}$. No entanto, não se observou mudanças microestruturais relevantes para temperaturas acima de $1000^{\circ} \mathrm{C}$, indicando o término do processo de sinterização. Usando o software image $\mathrm{J}$ foram medidos os diâmetros das pastilhas; Cada diâmetro foi medido 5 vezes, a tabela 5 apresenta a média dos diâmetros medidos em função da temperatura e o desvio padrão. $O$ diâmetro inicial das pastilhas tratada até $1000^{\circ} \mathrm{C}$ apresentado na tabela 3 não corresponde ao diâmetro inicial das pastilhas tratada acima de $1000^{\circ} \mathrm{C}$ na tabela 5 pois foram usados cadinhos distintos em cada processo.

TABELA 5: Valores médios dos diâmetros medidos utilizando o software image $\mathrm{J}$ em função da temperatura e o desvio padrão.

\begin{tabular}{cccccc}
\hline Temperatura $\left({ }^{\circ} \mathrm{C}\right)$ & $\mathbf{1 0 0 0}$ & $\mathbf{1 0 5 0}$ & $\mathbf{1 1 0 0}$ & $\mathbf{1 1 5 0}$ & $\mathbf{1 2 0 0}$ \\
\hline diâmetro médio $(\mathbf{m m})$ & 3,93 & 3,96 & 3,94 & 3,94 & 3,91 \\
desvio padrão & 0,04 & 0,04 & 0,02 & 0,06 & 0,07 \\
\hline
\end{tabular}

Pastilhas obtidas a partir de análises de DSC acima de $1000^{\circ} \mathrm{C}$, em porta amostra de alumina, foram analisadas por DRX para avaliar a ocorrência de cristalização observada nas curvas de DSC. A figura 34 mostra os difratogramas de raios $X$ das pastilhas obtidas. No final do processo endotérmico $\left(1000^{\circ} \mathrm{C}\right)$ já existem picos de $\mathrm{DRX}$ indicando a presença de fases cristalinas, como visto previamente. Em $1050^{\circ} \mathrm{C}$ e em $1150^{\circ} \mathrm{C}$ são os máximos 
de picos de cristalização na curva DSC e observa-se nos difratogramas de DRX intensidades superiores nessas temperaturas para as fases de aluminossilicato de magnésio e não identificadas, respectivamente. Também é possível observar a ausência de picos de difração relacionados a essas fases a $1300^{\circ} \mathrm{C}$ e o aparecimento de picos relacionados a indialita, indicando a fusão das fases de aluminossilicato de magnésio e fases não identificadas e cristalização da indialita.

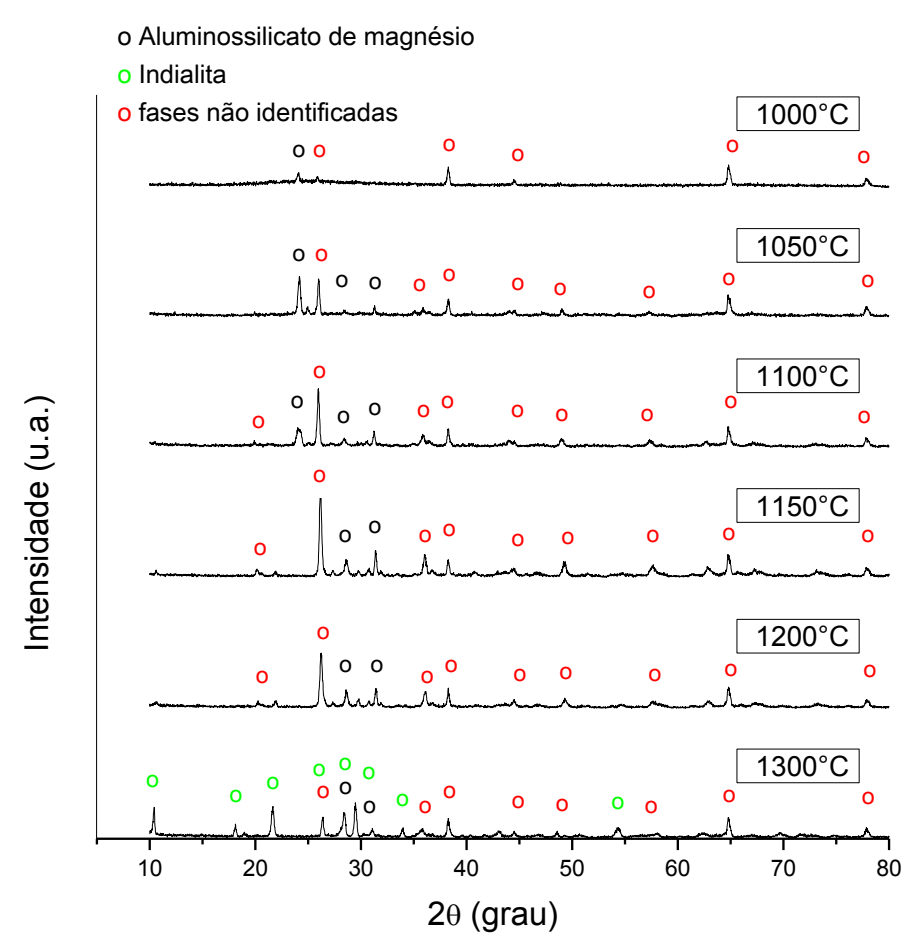

FIGURA 34: Difratograma de raios $\mathrm{X}$ das pastilhas tratadas de $1000^{\circ} \mathrm{C}$ a $1300^{\circ} \mathrm{C}$.

\subsection{Discussão Geral}

O processo de sinterização causa a mudança na linha base nas análises de DSC devido à retração da amostra e a consequente diminuição da área de contato entre a amostra e a base do cadinho, diminuindo o fluxo de calor medido pelo equipamento. Esse processo não é observado em vidros que amolecem e preenchem todo o fundo do cadinho e foi verificado no vidro aluminossilicato estudado e em uma composição de vidro fosfato. Quando a 
análise é realizada com a montagem de DTA o evento não é evidente, pois a medida é pontual. A correlação desse fenômeno só é possível quando o vidro retrai durante a análise térmica e o coeficiente de condutibilidade térmica do porta amostra é relativamente baixo conduzindo a um atraso na transferência de energia. Apesar do processo de sinterização ser um fenômeno exotérmico de pequena magnitude, o evento detectado na análise de DSC se sobrepõe e é detectado como uma mudança na linha base na direção endotérmica.

A variação da atmosfera de análise, tamanho de partícula do material analisado, forma do material e taxa de aquecimento não impedem a detecção do evento. Quando a granulometria é menor os eventos são deslocados para a direita, pois tanto a sinterização por fluxo viscoso quanto a cristalização ocorrem antes, pois são proporcionais à área de superfície específica.

Como a sinterização é um fenômeno de materiais particulados ela não ocorre em amostras na forma de monolito e em amostras que já foram previamente sinterizadas. 


\section{CONCLUSÕES}

O processo de sinterização por fluxo viscoso em vidros aluminossilicato pôde ser correlacionado a um evento endotérmico observado nas curvas de DSC quando porta amostras de alumina são utilizados durante as análises.

Este fato foi confirmado pelo aumento da densidade, formação de pescoços na interface das partículas, aumento do sinal de DSC em curvas isotermas, e a ausência da mudança da linha base em medidas de DSC subsequentes na mesma amostra.

Verificou-se também que o processo de sinterização se repete em diferentes atmosferas de análise e durante o processo não existe alteração na massa do material ou emissão de gases.

Quando a medida de análise térmica é pontual (DTA), mesmo utilizando porta amostra de alumina, o processo de sinterização não é detectado, confirmando que o fenômeno é devido a retração da superfície da amostra durante a sinterização e que é importante o contato da superfície da amostra com o dispositivo de medida.

A forma das amostras sendo microesferas ou pó não afeta o aparecimento da linha base, pois o processo de sinterização por fluxo viscoso é um fenômeno de materiais particulados, diferentemente do material na forma de monolito onde a mudança na linha base não aparece.

$O$ aumento na taxa de aquecimento desloca os eventos para a direita. Esse atraso ocorre quando se trata de fenômenos dependentes do tempo, como a sinterização e a cristalização detectadas. Já a diminuição na faixa granulométrica analisada desloca os eventos para a esquerda.

A partir das análises de DSC também foi possível verificar o início do processo de cristalização concomitante com o de sinterização. 


\section{APÊNDICE}

Foi feita uma montagem em um forno tubular para simular as condições durante a análise de DSC e produzir pastilhas. Esse forno foi utilizado na produção de pastilhas abaixo de $1000^{\circ} \mathrm{C}$ devido ao limite de temperatura do forno.

A figura 35 mostra a montagem. Em um forno tubular com um tubo de alumina por dentro, para proteger as resistências, foi colocado um tubo de alumina mais fino para permitir a inserção de um termopar e apoiar um cadinho de alumina. Um tubo de quartzo com uma janela foi utilizado para inserir o cadinho de DSC, utilizado para moldar as pastilhas, no centro da montagem.

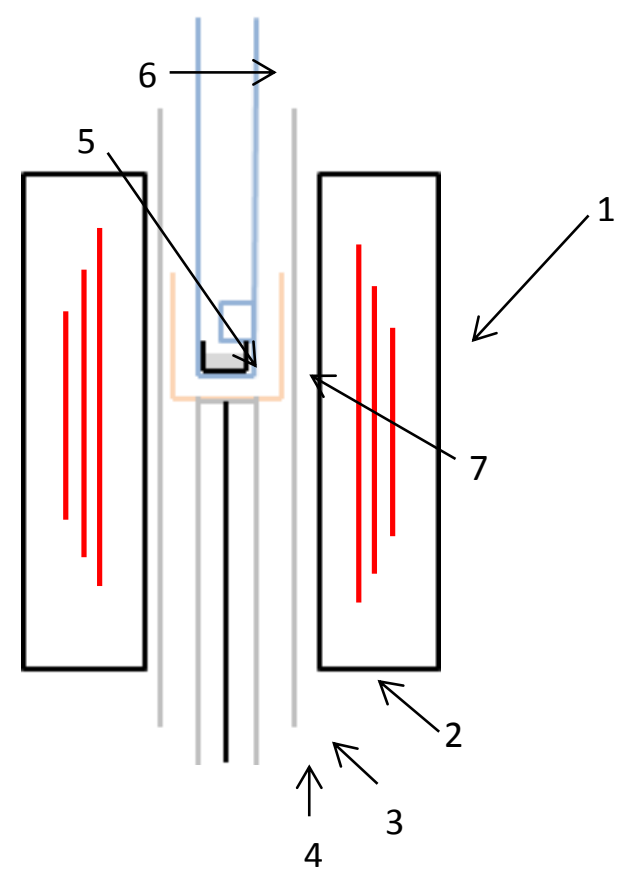

1- Forno tubular com resitências

2- Tubo de alumina grande

3- Tubo de alumina fino

4- Termopar

5- Cadinho de alumina

6- Tubo de quartzo com janela

7- Cadinho de alumina utilizado em análises de DSC

FIGURA 355: Desenho esquemático da montagem no forno tubular utilizada para produzir as pastilhas estudadas.

Para verificar o perfil de calor dentro do forno e calibrar a montagem, foi feito um experimento onde foi medida a temperatura no termopar inserido por 
baixo da montagem, em um outro termopar inserido na posição do cadinho de DSC e comparadas com a temperatura programada. Os valores obtidos estão representados na figura 36 .

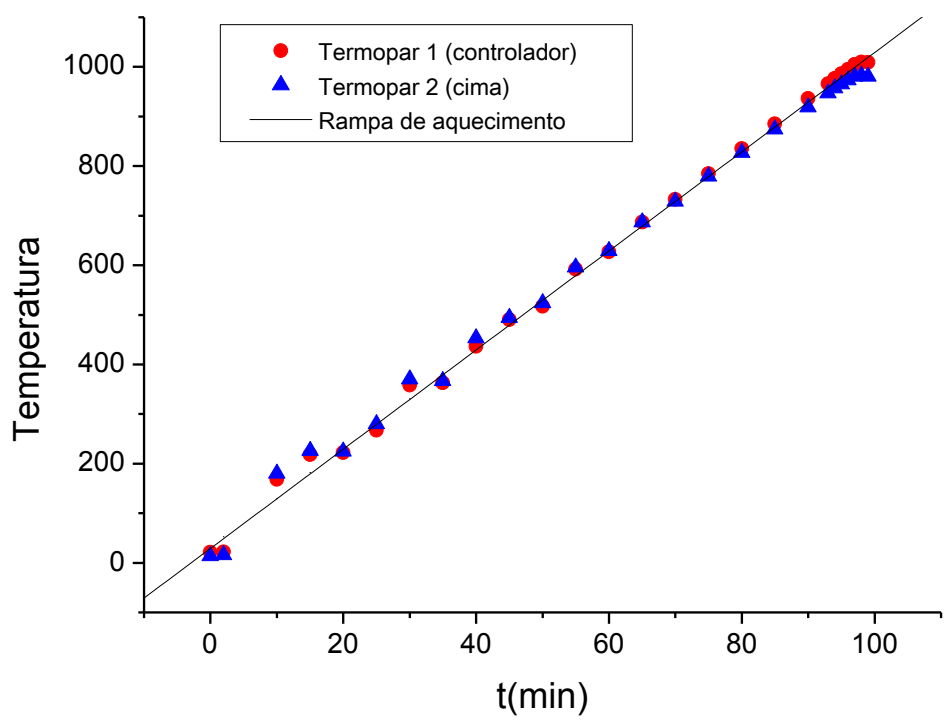

FIGURA 366: Comparação dos valores de temperatura em função do tempo de análise medidos no termopar controlador, no termopar auxiliar inserido no lugar da amostra e reta representando o programa de aquecimento de $10^{\circ} \mathrm{C} / \mathrm{min}$.

Os valores medidos foram muito próximos do estabelecido no programa de aquecimento, mostrando que não há uma perda grande de calor entre a posição em que está localizada a amostra e a posição do termopar controlador. Todas as pastilhas foram obtidas a $10^{\circ} \mathrm{C} / \mathrm{min}$, assim como foi feita a calibração. 


\section{REFERÊNCIAS BIBLIOGRÁFICAS}

[1] VENTRE, M. A.; WONDERGEM, M.; VAN DER TWEEL, I.;ET ALLYttrium-90 microsphere radioembolization for the treatment of liver malignancies: a structured meta-analysis. European Radiologw.19 n.4, p. 951, 2009.

[2] HYATT,M. J.;DAY, D. E. Glass Properties in the Yttria-Alumina-Silica System.Journal of the American Ceramic, v. 70, p. 283, 1987.

[3] ERBE, E. M.; DAY, D. E. Chemical durability of Y2O3-Al2O3-SiO2 glasses for the in vivo delivery of beta radiation. Jounal of Biomedical Material Research, v.27, p.233, 1301.

[4] EHRHARDT, G. J.; DAY, D. E.Nucl. Therapeutic use of ${ }^{90} Y$ microspheres, International Journal of Radiation Applications and Instrumentation.Medical Biology,V.14,p. 233, 1987.

[6] WANG, X. D.;YANG, R. J.;CAO, X. C.; TAN J., Li B. Dose Delivery Estimated by Bremsstrahlung Imaging and Partition Model Correlated with Response Following Intra-arterial Radioembolization with 32P-Glass Microspheres for the Treatment of Hepatocellular Carcinoma. Journal Gastrointest Surg, 2010.

[7] GOH, A. S-W.;CHUNG, A. Y.-F.; LO, R. H.-G.; LAU, T.-N.; YU S. W.-K.; CHANG, M.; SATCHITHANANTHAM, S.; LOONG, S. L.-E.; CHEE-ENG N. G. D.; LIM, B.-C.; CONNOR, S.;CHOW, P. K.-H. A novel approcch to brachytherapy in hepatocellular carcinoma using a phospherius 32 brachytherapy delivery device - A first-in-man study, International Journal of Radiation Oncology Biological Physics, 2006.

[8] WUNDERLICH, G. ;PINKERT, J.; STINTZ, M.; KOTZERKE, J. Labeling and biodistribution of different particle materials for radioembolization therapy with ${ }^{188}$ Re. Applied Radiation and isotopes, 2004.

[9] NIJSEN, J.F.W., VAN STEENBERGEN, M.J.;KOOIJMAN, H.;TALSMA, H.; KROON-BATENBURG, L.M.J.;VAN DE WEERT, M.;VAN RIJK, P.P; DE WITTE, A., VAN HET SCHIP, A.D.;HENNINK, W.E.Characterization of poly(Llactic acid) microspheres loadedb with holmium acetylacetonate. Biomaterials, v.22, 2001. 
[10] DASA, T.;CHAKRABORTYA, S.;SARMAB, H. D.;VENKATESHA, M.; BANERJEEA, S. Preparation of $166 \mathrm{Ho}$-oxine-lipiodol and its preliminary bioevaluation for the potential application in therapy of liver cancer; Nuclear Medicine Communications, 2009.

[11] HUMAN HEALTH SERIES №10. Trends and Practices in Diagnosis and Treatment of Hepatocellular Carcinoma. IAEA, 2010.

[12] COSTA, R. F. Desenvolvimentos de métodos de preparação de microesferas de polímeros e resinas marcadas com hólmio-166. 2008. Dissertação (Mestrado) - Instituto de Pesquisas Energéticas e Nucleares IPEN-CNEN/SP São Paulo. 94 p. Disponível em: <http://www.teses.usp.br> [13] VENTE, M. A. D.;DE WIT, T. C.;VAN DEN BOSCH, M. A. A. J.;BULT, W.;SEENVINCK, P. R.; ZONNENBERG, B. A.;DE JONG, H. W. A. M.;KRIJGER, G. C.;BAKKER, C. J. G.;VAN HET SCHIP, A. D.;NIJSEN, J. F. W.Holmium-166 poly (L-lactic acid) microsphere radioembolization of the liver: technical aspects studied in a large animal model. European Radiology, 2010.

[14] NIJSEN, J.F.W.;VAN HET SCHIP, A. D.;VAN STEENBERGEN, M. J.;ZIELHUIS, S. W.;KROON-BATENBURG, L.M.J.;VAN DE WEERT, M.;VAN RIJK, P.P.;HENNINK, W.E. Influence of neutron irradiation on holmium acetylacetonate loaded poly(l-lactic acid) microspheres, Biomaterials, 2001. [15] VENTE, M. A. D.;NIJSEN, J. F. W.; DE ROOS, R.;VAN STEENBERGEN, M. J.;KAAIJK, C. N. J.;KOSTER-AMMERLAAN, M. J. J.;DE LEEGE, P. F. A.;HENNINK, W. E.; VAN HET SCHIP, A. D.; KRIJGER, G. C. Neutron activation of holmium poly(L-lactic acid) microspheres for hepatic arterial radioembolization: a validation study.Biomedical Microdevices,2009.

[16] SMITS, M. L. J.;NIJSEN. J. F. W.; VAN DEN BOSCH, M. A. A. J.; LAM, M. G. E. H.; VENTE. M. A. D.; HUIJBREGTS, J. E.;VAN HET SCHIP, A. D., ELSCHOT, M.; BULT, W.;DE JONG, W. A. M.;MEULENHOFF, P. C. W.;ZONNENBERG, B. A. Holmium-166 radioembolization for the treatment of patients with liver metastases : design of the phase I HEPAR trial. Journal of experimental and clinical cancer research, 2010.

[17] SENE, F. F.; MARTINELLI, J. R.; OKUNO, E. Synthesis and characterization of phosphate glass microspheres for radiotherapy applications.Journal of Non-Crystalline Solids, 2008. 
[18] BARROS, E. C.Estudo do Processo de Esferolização de Partículas Vítreas Visando à Aplicação em Radioterapia Interna Seletiva. 2012.Dissertação (Mestrado)Instituto de Pesquisas Energéticas e Nucleares - IPEN-CNEN/SP, São Paulo. 116 p. Disponível em: <http://www.teses.usp.br> Acesso em: 20 de fevereiro de 2013.

[19] ALVEZ, O. L; GIMENEZ, I. F.; MAZALI, I. O. Vidros.Química Nova na Escola., Cadernos Temáticos, 2001.

[20] SHELBY, J.E. Introduction to glass science and technology. Cambridge: The Royal Society of Chemistry, 1997.

[21] Navarro J. M. F. El vidrio,2. Ed. CSIC, Madrid,1991.

[22] ZACHARIASEN, W.H. The atomic arrangement in glass. Jouranl of the American Chemical Society, v. 54, p. 3841-3851, 1932.

[23] GUPTA, P.K. Non-crystalline solids: glasses and amorphous solids. Journal of Non-Crystalline Solids, v.195, p. 158-164, 1996.

[24] FOKIN, V. M.; ZANOTTO, E. D.;YURITSYN, N. S.;SCHMELZER, J.W.P.Homogeneous crystal nucleation in silicate glases: $A 40$ year perspective.Journal of Non-Cristalline Solids, v.2741, p.2681, 2006.

doi:10.1016/j.jnoncrysol.2006.02.074

[25] VIEIRA, H.;Avaliação da cristalização e durabilidade química de vidros niobofosfatos visando à imobilização de rejeitos radioativos. 2008. Dissertação (Mestrado) - Instituto de Pesquisas Energéticas e Nucleares - IPEN-CNEN/SP, São Paulo. 68 p. Disponível em: <http://www.teses.usp.br> Acesso em: 18Agosto 2014.

[26] VARSHNEYA., A.K. Fundamentals of inorganic glasses, London: Academic Press, 1994.

[27] MCLELLAN, G. W.; SHAND E. B. Glass Engineering Handbook, McGrawHill Book Company, 1984.

[28] SADDEK Y. B. Structural interpretations of aluminosilicate glasses. Physica B, p. 19-24, 2005. doi: 10.1016/jphysb.2005.02.029 
[29] REED, J. S. Principles of Ceramics Processing, 2. ed. Wiley,1995.

[30] Rahaman, M. N. Ceramic Processing and Sintering. CRC Press, 2003

[31] CHIANG, Y. M.;BIRNIE III, D.;KINGERY, W. D.;Physical CeramicsPrinciples for Ceramic Science and Engineering. Wiley - The MIT series in materials science and engineering, 1997.

[32] FRENKEL, J.J. Journal of Physics (USSR) v.9, p. 385,1945.

[33] PRADO, M. O.; NASCIMENTO, M. L. F.; ZANOTTO, E. D. On the sinterability of crystallizing glass powders. Journal of Non-Crystalline Solids. v.354, p.4589-4597, 2008.

[34] MACKENZIE, J.K.; SHUTTLEWORTH R. A Phenomenological Theory of Sintering. Proceedings of the Physical Society. V.62, Sect. B, 1949.

[35] GABBOTT, P. Principles and Applications ofThermal Analysis. 1.ed. Blackwell Publishing Ltd,2008

[36] DOS SANTOS, W. J.; Materials Characterization Techniques: Applications and Features. ScientiaPlena. v. 5, n.6, 2009.

[37] STOJANOVIC, Z.; MARKOVIC, S. Determinatios of Particle Size Distributions by Laser Diffraction. Technic - New Materials v. 21, 2012 [38] Cullity, B. D. Elements of $X$ ray diffraction. Addison-Wesley Publishing Company, Inc., 1956

[39] MONTEIRO, W. A.; BUSO, S. J. Caracterização de Materiais por métodos Físicos - Tecnicas Experimentais e Aplicações Práticas. Apostila dada na disciplina: TNM5747 - Técnicas de Microscopia Eletrônica Aplicada a Materiais realizada em 2013.

[40] SALVADOR, V. L. R. Espectrometria de Fluorescência de raios X. Apostila dada na disciplina:IPN - 0014, 2010.

[41] MOURA, M. J.; FIGUEIREDO, M. M. Aplicação das Técnicas de Picnometria de Gás e de Porosimetria de Mercúrio à Caracterização da Madeira de E. Globulus. Silva Lusitana,v. 10, n. 2, p. 207 - 216, 2002.

[42] GITZEN, W. H. Alumina as a Ceramic Material. Wiley-American Ceramic Society, 1970

[43] LIDE, D. R. CRC Handbook of Chemistry and Physics, 84.ed.. CRC Press. Boca Raton, Florida, 2003. 
[44] KAISEMBERGER, E. From DTA to DSC and comparison with calculated DTA (c-DTA, SDTA) -From measured differential signals to calculated difference signals- Informativo da NETZSCH-Gerätebau $\mathrm{GmbH}$, Selb/Germany, 2005.

[45] <webbook.nist.gov/cgi/cbook.cgi?|D=C124389\&Mask=200> acessado em 3 de novembro de 2014. 